\title{
Parthenolide generates reactive oxygen species and autophagy in MDA-MB231 cells. A soluble parthenolide analogue inhibits tumour growth and metastasis in a xenograft model of breast cancer
}

\author{
A D’Anneo ${ }^{1,5,6}$, D Carlisi ${ }^{2,5,6}$, M Lauricella $^{2}$, R Puleio ${ }^{3}$, R Martinez ${ }^{1}$, S Di Bella ${ }^{3}$, P Di Marco ${ }^{3}$, S Emanuele ${ }^{2}$, R Di Fiore ${ }^{1}$, A Guercio $^{3}$, \\ $R$ Vento ${ }^{1,4}$ and $G$ Tesoriere ${ }^{\star, 1,4}$
}

Triple-negative breast cancers (TNBCs) are clinically aggressive forms associated with a poor prognosis. We evaluated the cytotoxic effect exerted on triple-negative MDA-MB231 breast cancer cells both by parthenolide and its soluble analogue dimethylamino parthenolide (DMAPT) and explored the underlying molecular mechanism. The drugs induced a dose- and timedependent decrement in cell viability, which was not prevented by the caspase inhibitor z-VAD-fmk. In particular in the first hours of treatment (1-3 h), parthenolide and DMAPT strongly stimulated reactive oxygen species (ROS) generation. The drugs induced production of superoxide anion by activating NADPH oxidase. ROS generation caused depletion of thiol groups and glutathione, activation of c-Jun N-terminal kinase (JNK) and downregulation of nuclear factor kB (NF-kB). During this first phase, parthenolide and DMAPT also stimulated autophagic process, as suggested by the enhanced expression of beclin-1, the conversion of microtubule-associated protein light chain 3-I (LC3-I) to LC3-II and the increase in the number of cells positive to monodansylcadaverine. Finally, the drugs increased RIP-1 expression. This effect was accompanied by a decrement of pro-caspase 8, while its cleaved form was not detected and the expression of C-FLIPS markedly increased. Prolonging the treatment $(5-20 \mathrm{~h})$ ROS generation favoured dissipation of mitochondrial membrane potential and the appearance of necrotic events, as suggested by the increased number of cells positive to propidium iodide staining. The administration of DMAPT in nude mice bearing xenografts of MDA-MB231 cells resulted in a significant inhibition of tumour growth, an increment of animal survival and a marked reduction of the lung area invaded by metastasis. Immunohistochemistry data revealed that treatment with DMAPT reduced the levels of NF-kB, metalloproteinase-2 and -9 and vascular endothelial growth factor, while induced upregulation of phosphorylated JNK. Taken together, our data suggest a possible use of parthenolide for the treatment of TNBCs.

Cell Death and Disease (2013) 4, e891; doi:10.1038/cddis.2013.415; published online 31 October 2013

Subject Category: Cancer

Triple-negative breast cancers (TNBCs) are clinically aggressive forms of breast cancer ${ }^{1}$ which do not express oestrogen, progesterone and HER-2/neu receptors. ${ }^{2}$ They are unresponsive to endocrine agents or trastuzumab ${ }^{3}$ and are typically treated with a combination of therapies such as surgery, radiation therapy and chemotherapy. ${ }^{4-6}$ As standard chemotherapy with anthracyclines, taxanes and platinum agents is characterised by a high rate of acquired resistance, ${ }^{5,7-9}$ a novel treatment strategy for TNBCs is urgently needed.

\footnotetext{
${ }^{1}$ Department of Biological, Chemical and Pharmaceutical Sciences and Technologies, Polyclinic, Laboratory of Biochemistry, University of Palermo, Via del Vespro 129, Palermo, Italy; ${ }^{2}$ Department of Experimental Biomedicine and Clinical Neurosciences, Polyclinic, Laboratory of Biochemistry, University of Palermo, Via del Vespro 129, Palermo, Italy; ${ }^{3}$ Istituto Zooprofilattico Sperimentale della Sicilia 'A. Mirri', Area Diagnostica Virologica, Via Gino Marinuzzi 3, Palermo, Italy and ${ }^{4}$ Sbarro Institute for Cancer Research and Molecular Medicine, College of Science and Technology, Temple University, Philadelphia, PA, USA

*Corresponding author: G Tesoriere, Department of Experimental Biomedicine and Clinical Neurosciences, Polyclinic, Laboratory of Biochemistry, University of Palermo, via del Vespro 129, 90127 Palermo, Italy. Tel: +39 091 6552459; Fax: +39 091 6552449; E-mail: giovanni.tesoriere @unipa.it

${ }^{5}$ These authors contributed equally to this work.

${ }^{6}$ These authors shared first authorship.

Keywords: parthenolide; ROS; NOX; autophagy; breast cancer xenograft

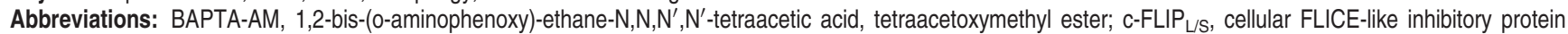
long/short; DHE, dihydroethidium; DMAPT, dimethylamino parthenolide; DMSO, dimethyl sulfoxide; DTNB, 5,5'-dithiobis-(2-nitrobenzoic acid); $\Delta \psi$ m, mitochondrial membrane potential; EMT, epithelial-mesenchymal transition; ERK1/2, extracellular signal-regulated kinase 1/2; FADD, Fas-associated death domain; FCCP, trifluorocarbonylcyanide phenylhydrazone; FITC, fluorescein isothiocyanate; Fluo-3AM, 4-(6-Acetoxymethoxy-2,7-dichloro-3-oxo-9-xanthenyl)-4'-methyl-2,2' (ethylenedioxy)dianiline-N,N, $\mathrm{N}^{\prime}, \mathrm{N}^{\prime}$-tetraacetic acid tetrakis(acetoxymethyl) ester; GSH, glutathione; $\mathrm{H}_{2}$-DCFDA, 5-(and-6)-carboxy-2', $7^{\prime}$-dichlorodihydrofluorescein diacetate; HER-2, human epidermal growth factor receptor 2; JC-1, 5,5',6,6'-tetrachloro-1,1',3,3'- tetraethylbenzimidazolylcarbocyanine iodide; JNK, c-Jun N-terminal kinase; LC3, microtubule-associated protein light chain 3; 3-MA, 3-methyladenine; MDC, monodansylcadaverine; MEK1/2, mitogen-activated protein kinase kinase 1/2; MMP-2, metalloproteinase-2; MMP-9, metalloproteinase-9; MTT, (3-(4,5-dimethylthiazol-2-yl)-2,5-diphenyltetrazolium bromide; NAC, N-acetylcysteine; Nec-1, necrostatin-1; NF-kB, nuclear factor kB; NOX, NADPH oxidase; PI, propidium iodide; PI3K, phosphatidylinositide 3-kinase; PN, parthenolide; RIP-1, receptor-interacting protein-1; ROS, reactive oxygen species; SOD, superoxide dismutase; STAT-3, signal transducer and activator of transcription 3; TCA, trichloroacetic acid; TNBC, triple-negative breast cancer; VEGF, vascular endothelial growth factor; z-VAD-fmk, benzyloxycarbonyl-Val-Ala-Asp (OMe)-fluoromethylketone

Received 13.6.13; revised 03.9.13; accepted 06.9.13; Edited by M Agostini
} 
Parthenolide, a sesquiterpene lactone found in Tanacetum parthenium, known for its anti-inflammatory activity, ${ }^{10}$ is considered as a novel anti-tumour agent. Parthenolide induces cytotoxicity in prostate ${ }^{11}$ pancreatic ${ }^{12}$ and colorectal cancers, ${ }^{13}$ multiple myeloma ${ }^{14}$ and leukaemia cells, ${ }^{15}$ but is ineffective in normal tissues. ${ }^{16}$ It exerts antitumor activity also in breast cancer cells, ${ }^{17}$ inducing DNA-binding inhibition of two transcription factors, the nuclear factor kB (NF-kB) and the signal transducer and activator of transcription 3 (STAT-3), together with reactive oxygen species (ROS) generation and c-Jun N-terminal kinase (JNK) activation. Finally, parthenolide, in combination with docetaxel, improves survival in a xenograft model of breast cancer and reduces lung metastases. ${ }^{18}$ However, the mechanisms of these effects are unknown today.

Recently, we showed that parthenolide exerts cytotoxicity on osteosarcoma and melanoma cells ${ }^{19}$ through a caspaseindependent mechanism correlated with ROS generation.

The present paper shows that parthenolide induces in MDA-MB231 cells, the most studied TNBC cells, a caspase-independent form of death, stimulating oxidative stress and autophagy.

Despite the high efficacy of parthenolide in vitro, its pharmacological use is difficult owing to the scarce solubility. ${ }^{20}$ Recently, a dimethylamino analogue of parthenolide (DMAPT) has been generated, which improves solubility and bioavailability and exhibits an acceptable toxicological profile in animal studies. ${ }^{21,22}$ DMAPT eradicates primary leukaemia stem cells ${ }^{21}$ and suppresses in vivo the growth of prostate, ${ }^{22}$ lung and bladder cancers, ${ }^{23}$ by targeting NF-kB and generating ROS.

In this paper, we also demonstrate that DMAPT significantly decreases tumour growth in mice bearing xenografts of MDAMB231 cells and enhances survival of treated mice. Moreover, immunohistochemical studies show that DMAPT decreases in vivo the levels of metalloproteinase-2 (MMP-2), metalloproteinase-9 (MMP-9) and vascular endothelial growth factor (VEGF), all factors involved in metastatic events.

\section{Results}

Parthenolide effect on cell viability and intracellular calcium level. Treatment with parthenolide or DMAPT inhibited viability of MDA-MB231 cells, assessed by MTT method, in a dose- and time-dependent manner (Figures 1a and b). After $16 \mathrm{~h}$ of exposure to $25 \mu \mathrm{M}$ cell viability decreased by $64 \%$ with parthenolide and $70 \%$ with DMAPT. $\mathrm{N}$-acetylcysteine (NAC; $2 \mathrm{mM}$ ), an effective scavenger of free radicals, suppressed this effect with both the drugs, while $50 \mu \mathrm{M}$ necrostatin-1 (Nec-1), an inhibitor of receptorinteracting protein-1 (RIP-1) kinase, ${ }^{24}$ caused a partial reduction. Conversely, $100 \mu \mathrm{M}$ z-VAD-fmk, a general inhibitor of caspases, did not modify parthenolide or DMAPT effect (Figure 1c).

To ascertain the cause of the inhibitory effect and to differentiate apoptotic and necrotic cells, the cells were stained with Annexin V-fluorescein isothiocyanate (FITC) and propidium iodide (PI) and analysed by flow cytometry at 8 and $16 \mathrm{~h}$ of treatment with $25 \mu \mathrm{M}$ parthenolide (Figure 1d) or DMAPT (Supplementary Figure S2A). Figure 1d shows that already at $8 \mathrm{~h}$ cells undergoing necrosis (Annexin V-negative/ PI-positive cells, C1) amounted to $37.8 \%$ of the total. However a population of cells positive to both Annexin V and PI (C2) was observed at $8 \mathrm{~h}(14.3 \%)$ and increased at $16 \mathrm{~h}(24.6 \%)$. These cells could be late apoptotic or necrotic dead cells. We concluded that they are necrotic dead cells, because 8 or $16 \mathrm{~h}$ of treatment did not significantly modify the percentage of early apoptotic cells (Annexin V-positive/PI-negative cells, C4) from the control. Moreover, Nec-1, which inhibits RIP-1-induced necrosis, strongly reduced the percentage of cells positive to both Annexin $\mathrm{V}$ and $\mathrm{PI} .{ }^{25}$

Next we analysed the drug impact on cell cycle. After $4 \mathrm{~h}$ of exposure fraction of cells in G2/M increased from 15 to 35\% with both parthenolide (Supplementary Figure S1A) and DMAPT (Supplementary Figure S2B). These effects persisted until $16 \mathrm{~h}$ of treatment.

Moreover, parthenolide induced morphological changes in MDA-MB231 cells. Under light microscopy control cells exhibited an adhesive and widened morphology. At $1 \mathrm{~h}$ of exposure to $25 \mu \mathrm{M}$ the cells assumed a rounded shape and at $4 \mathrm{~h}$ were deprived of anchorage and floated in the medium (Figure 1e). All these effects were suppressed by 2 mM NAC.

Parthenolide treatment rapidly increased intracellular $\mathrm{Ca}^{2+}$ level. The effect, appeared at $30 \mathrm{~min}$ of exposure to $15 \mu \mathrm{M}$ parthenolide, reached the maximum at $1 \mathrm{~h}$ and then declined at 2 and $3 \mathrm{~h}$ (Figure 1F).

Parthenolide induces production of radical species. NADPH oxidase (NOX) is a multisubunit enzyme, which catalyses the transfer of an electron to $\mathrm{O}_{2}$ to generate $\mathrm{O}_{2}^{-}$, a highly ROS.

Parthenolide is known to activate NOX and to mediate intense oxidative stress in prostate cancer cells ${ }^{26}$ and multiple myeloma cells. ${ }^{27}$ To ascertain whether parthenolide stimulated NOX also in MDA-MB231 cells, we evaluated its effect on superoxide anion production. Analysis performed by dihydroethidium (DHE) revealed by direct estimation using fluorescence microscope the appearance of intense red fluorescence after $2-6 \mathrm{~h}$ of treatment with $25 \mu \mathrm{M}$ parthenolide. This effect was abrogated both by apocynin, a specific inhibitor of NOX activity, ${ }^{28,29}$ and BAPTA-AM, ${ }^{30}$ an intracellular $\mathrm{Ca}^{2+}$ chelator. In conclusion, parthenolide stimulated NOX activation through a mechanism mediated by $\mathrm{Ca}^{2+}$. Figure $2 \mathrm{a}$ shows the results obtained at $3 \mathrm{~h}$ of treatment.

A group of oxidoreductases, known as superoxide dismutases, catalyse the dismutation of $\mathrm{O}_{2}^{-}$into oxygen and $\mathrm{H}_{2} \mathrm{O}_{2}$, a less aggressive form of ROS. The fluorochrome $\mathrm{H}_{2}-$ DCFDA, a general indicator of cellular ROS level, was used to ascertain ROS level by direct estimation using fluorescence microscope. A time course study (Figures $2 \mathrm{~b}$ and $\mathrm{c}$ ) with $15 \mu \mathrm{M}$ parthenolide showed that ROS generation rapidly increased, reaching the maximum at $1-3 \mathrm{~h}$, when $90 \%$ of cells exhibited green fluorescence. Then the effect declined to $30 \%$ at $16 \mathrm{~h}$ of exposure. ROS generation (Figures $2 \mathrm{~d}$ and e) was suppressed both by NAC and BAPTA-AM, whatever the time of treatment was. These results indicated an important role exerted by $\mathrm{Ca}^{2+}$ in ROS generation. Moreover apocynin, an inhibitor of NOX activity, markedly reduced ROS level at $1 \mathrm{~h}$ of treatment, while at $8 \mathrm{~h}$ a lower effect was found. Therefore, in the first phase of treatment, ROS generation primarily 


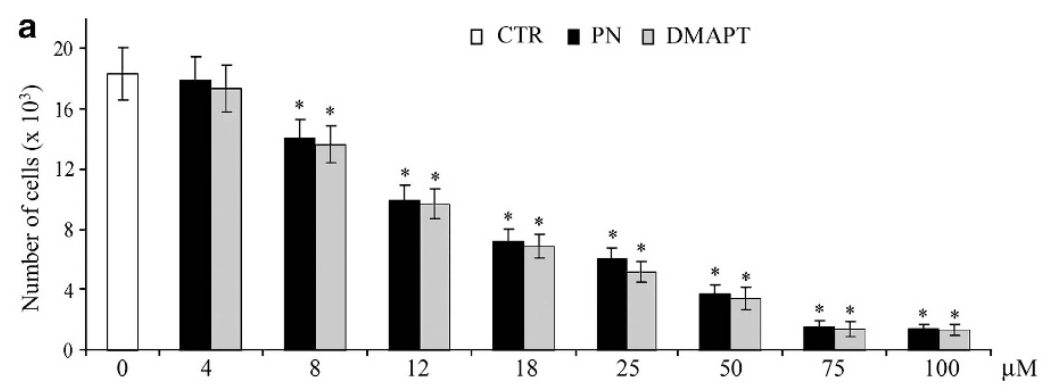

b 口 CTR - $25 \mu \mathrm{M}$ PN $\square 25 \mu \mathrm{M}$ DMAPT

C

- $25 \mu \mathrm{M}$ PN $\square 25 \mu \mathrm{M}$ DMAPT
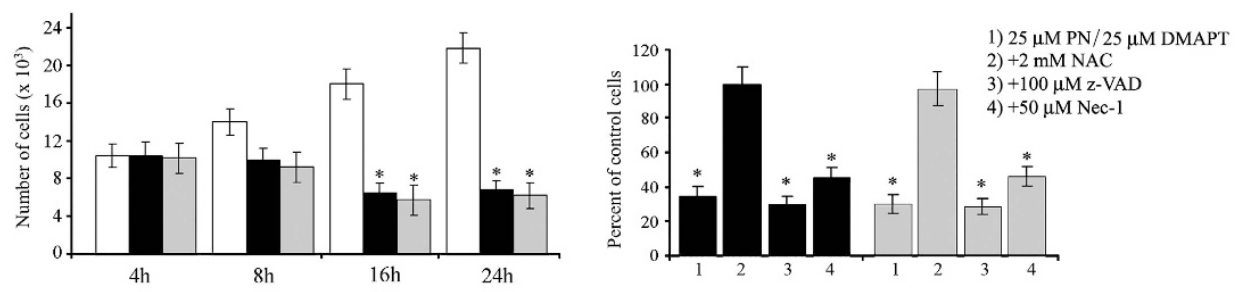

d
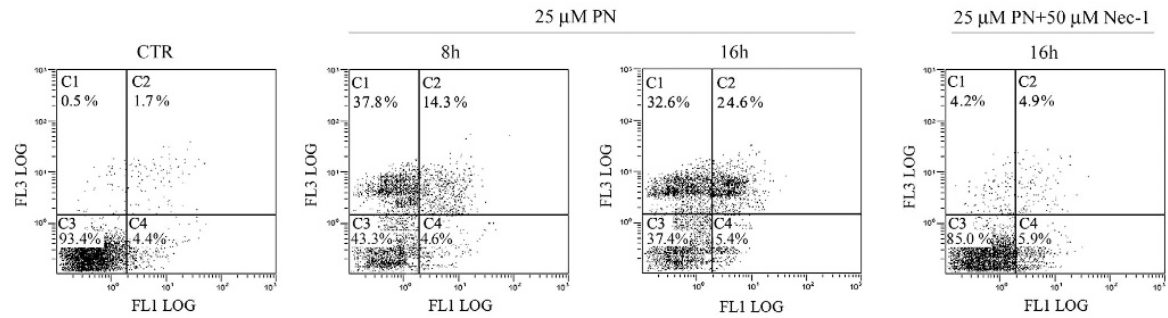

e

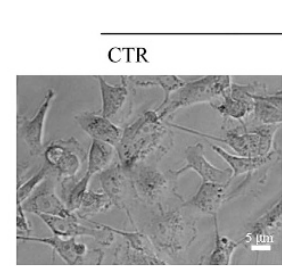

$4 \mathrm{~h}$

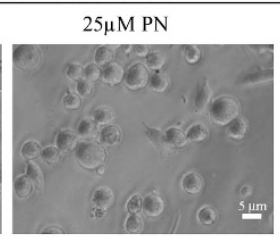

$25 \mu \mathrm{M} \mathrm{PN}+2 \mathrm{mM} \mathrm{NAC}$

f

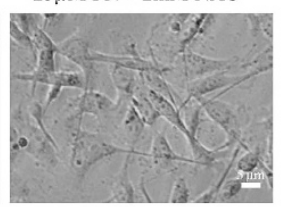

$15 \mu \mathrm{M}$ PN
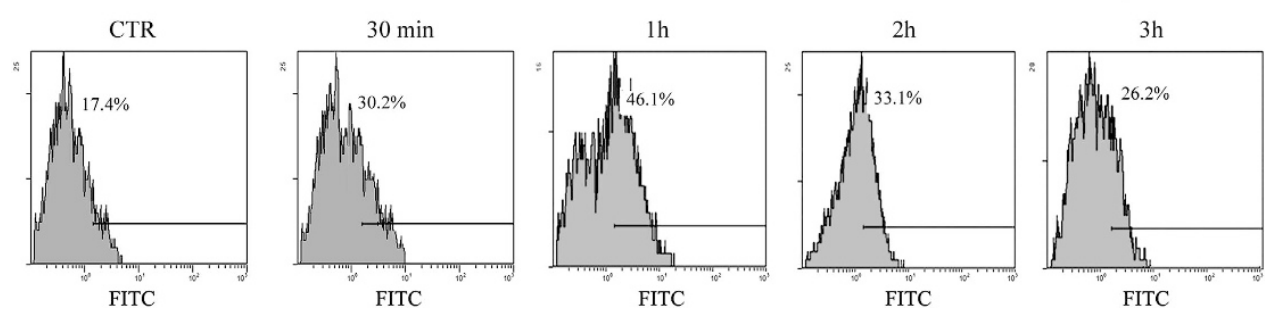

Figure 1 Treatment with parthenolide or DMAPT inhibits proliferation and induces necrosis of MDA-MB231 cells. (a-c) Cytotoxic effects exerted by both parthenolide and DMAPT on cell viability. Cells $\left(8 \times 10^{3} /\right.$ well) were treated (a) for $16 \mathrm{~h}$ with different doses of parthenolide or DMAPT and (b) for various times with $25 \mu \mathrm{M}$ parthenolide or $25 \mu \mathrm{M}$ DMAPT. (c) Cells were treated for $16 \mathrm{~h}$ with $25 \mu \mathrm{M}$ parthenolide or $25 \mu \mathrm{M}$ DMAPT without or with $2 \mathrm{mM}$ NAC, $100 \mu \mathrm{M} z$-VAD-fmk, $50 \mu \mathrm{M}$ Nec-1. Cell viability was assessed by MTT assay, as reported in Materials and Methods. (d) Analysis by Annexin V/PI double-staining assay of parthenolide effects. Cells $\left(2 \times 10^{5} /\right.$ well) were treated for 8 or $16 \mathrm{~h}$ with $25 \mu \mathrm{M}$ parthenolide without or with $50 \mu \mathrm{M} \mathrm{Nec}-1$. After treatment, cells were stained with annexin V-FITC and PI and analysed by flow cytometry. C1 is related to necrotic cells (Annexin V-FITC-negative and PI-positive), C2 were cells in end stage of apoptosis or necrotic dead cells (Annexin V-FITC-positive and PI-positive), C3 were viable cells (Annexin V-FITC-negative and PI-negative) and finally C4 is related to cells undergoing early apoptosis (Annexin V-FITC-positive and PI-negative). (e) Morphological effects induced by parthenolide, observed under light microscopy at $\times 200$ magnification. Cells $\left(8 \times 10^{3} /\right.$ well) were treated for $4 \mathrm{~h}$ with $25 \mu \mathrm{M}$ parthenolide without or with $2 \mathrm{mM} \mathrm{NAC}$. Scale bar, $5 \mu \mathrm{m}$. (f) The effects of parthenolide on the levels of intracellular $\mathrm{Ca}^{2+}$. Cells $\left(2 \times 10^{5} /\right.$ well) were treated with $15 \mu \mathrm{M}$ parthenolide for various times. At the end, cells were loaded with $5 \mu \mathrm{M}$ Fluo-3 AM for $60 \mathrm{~min}$ and then immediately analysed using flow cytometry. In (a-c) values are the means of three independent experiments \pm S.E. ${ }^{*} P<0.01$ versus untreated control. In (d- $\left.\mathbf{f}\right)$ the results are representative of three independent experiments

depended on NOX activation. Differently Rotenone and trifluorocarbonylcyanide phenylhydrazone (FCCP) ${ }^{31}$ which inhibit mitochondrial electron transport system, produced a little effect at $1 \mathrm{~h}$ and a greater effect at $8 \mathrm{~h}$ of exposure, suggesting that mitochondrial production of ROS increased in the second phase of treatment (Figures 2d and e). 
Results concerning generation of both superoxide anion and ROS were confirmed by cytofluorimetric analysis either using parthenolide (Supplementary Figure S1B, C) or DMAPT (Supplementary Figure S2C, D).
Parthenolide activates ERK1/2, JNK and RIP-1. Western blotting analysis (Figure 3a) demonstrated that parthenolide increased in a dose-dependent manner the levels of phosphorylated ERK1/2 (p-ERK1/2), phosphorylated JNK a

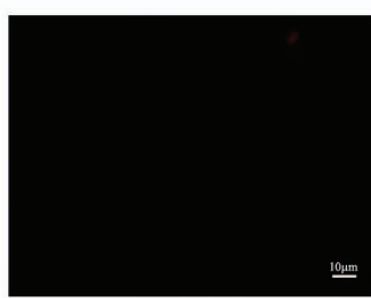

$25 \mu \mathrm{M}$ PN

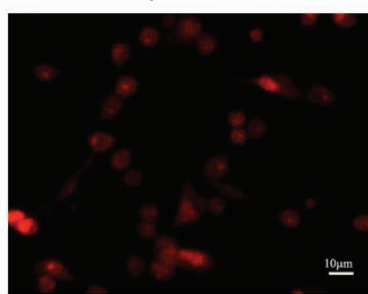

$25 \mu \mathrm{M}$ PN $+100 \mu \mathrm{M}$ apocynin
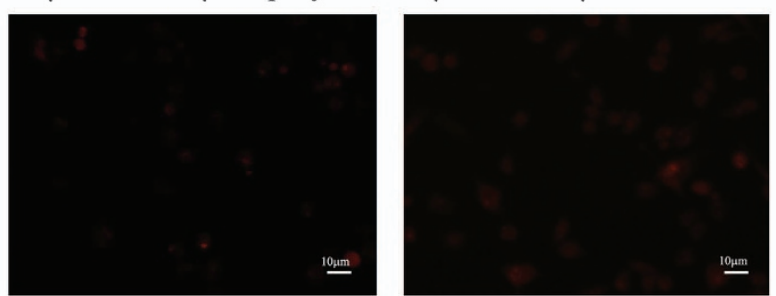

b
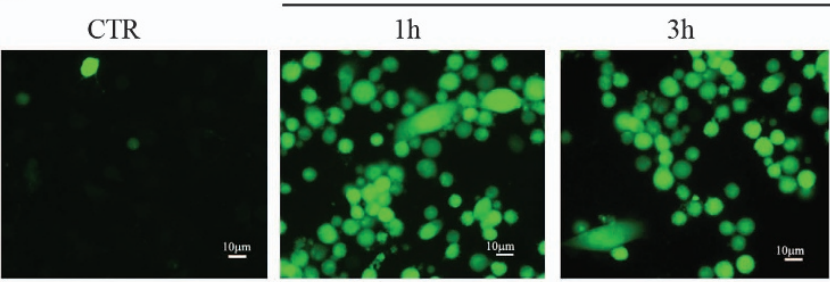

$15 \mu \mathrm{M}$ PN
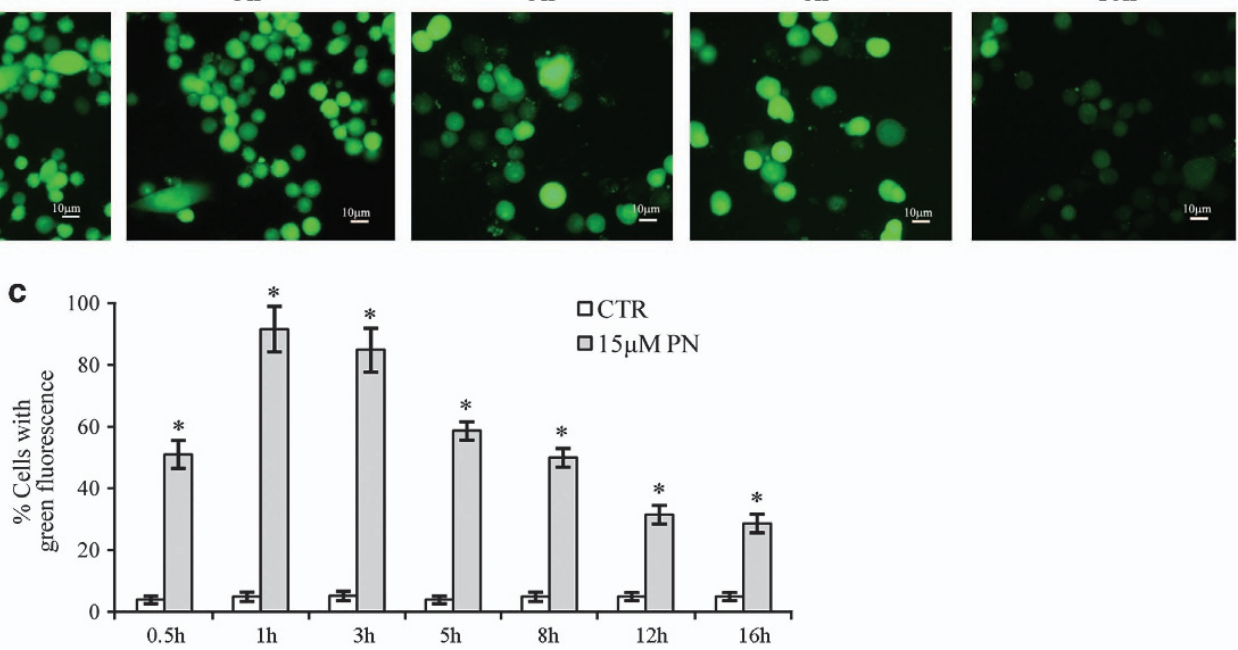

d

$15 \mu \mathrm{M}$ PN
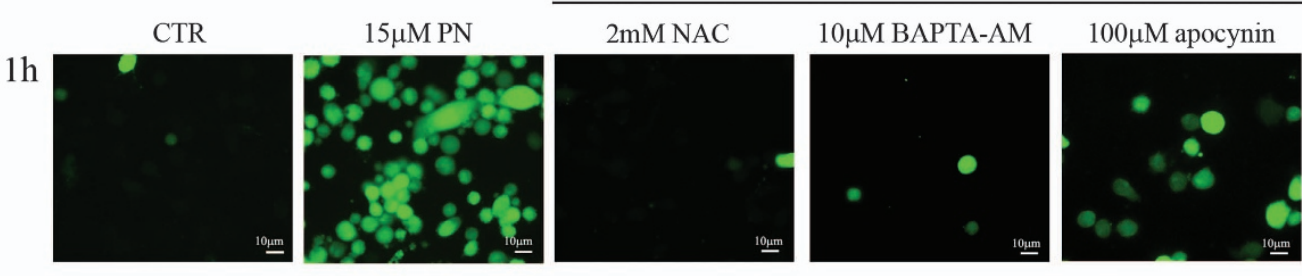

$1 \mu \mathrm{M}$ Rotenone
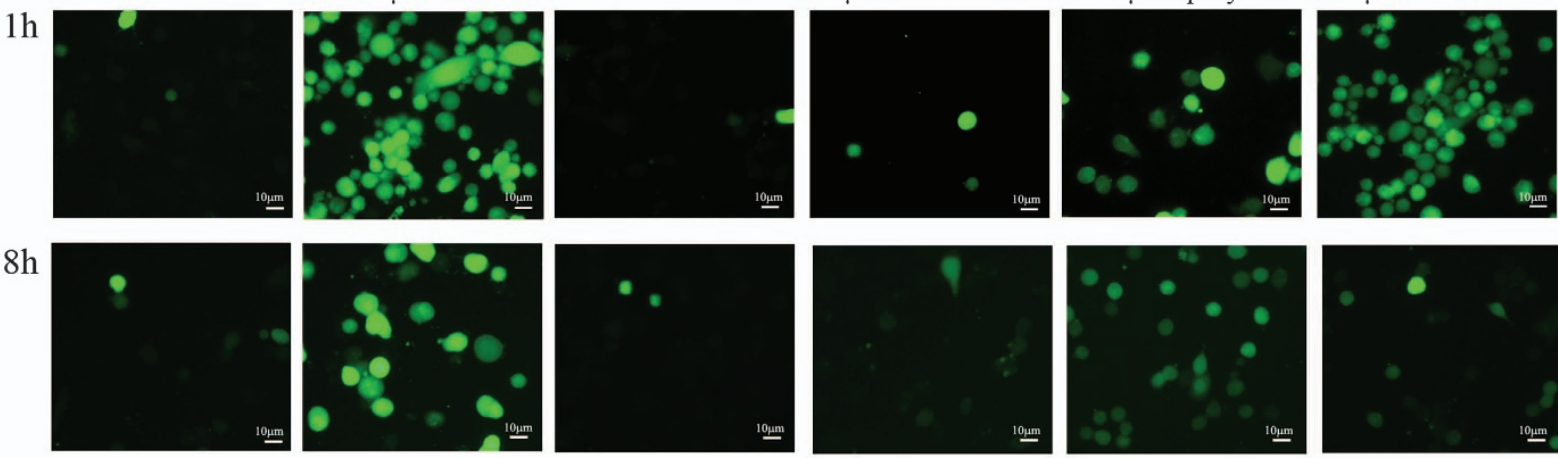

e

$1 \mathrm{~h}$

$8 \mathrm{~h}$
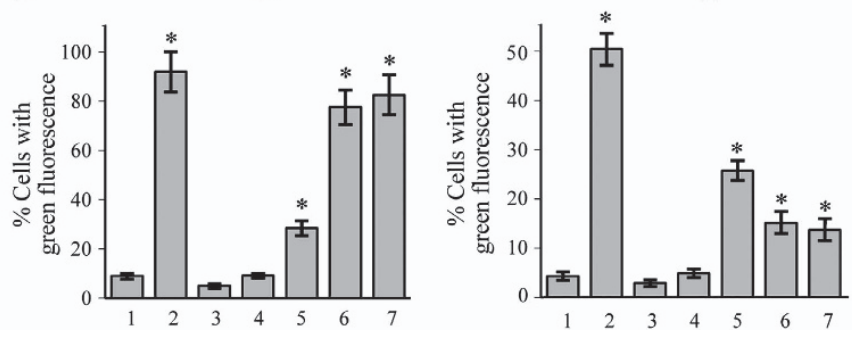

1) CTR

2) $15 \mu \mathrm{M} P N$

3) $15 \mu \mathrm{MPN}+2 \mathrm{mM} \mathrm{NAC}$

4) $15 \mu \mathrm{M} P N+10 \mu \mathrm{M}$ BAPTA-AM

5) $15 \mu \mathrm{M} \mathrm{PN}+100 \mu \mathrm{M}$ apocynin

6) $15 \mu \mathrm{MPN}+1 \mu \mathrm{M}$ Rotenone

7) $15 \mu \mathrm{M} \mathrm{PN}+1 \mu \mathrm{M}$ FCCP 
(p-JNK) and RIP-1. These effects appeared at $1 \mathrm{~h}$ of treatment and increased at 2-4h. Parthenolide effect on p-ERK1/2 level was prevented by U0126, an inhibitor of the mitogen-activated protein kinase kinase 1/2 (MEK1/2), ${ }^{32}$ which is the upstream ERK1/2 regulator. ${ }^{33}$ Instead apocynin, NAC and finally SP600125, a specific inhibitor of JNK activity, ${ }^{34}$ did not modify parthenolide effect on $p$-ERK1/2 level (Figure 3a). Therefore, NOX and JNK activation as well as ROS generation lie downstream of ERK1/2 activation. This conclusion agrees with the finding of Moon et al., ${ }^{32}$ which demonstrated that ERK1/2 activation, induced by MEK1/2, enhanced NOX transcription and ROS generation.

Moreover, our results show that U0126, apocynin, NAC and SP600125 prevented parthenolide effect on JNK activation (Figure 3a), which therefore lies downstream of the activation of ERK1/2 and NOX and the production of ROS. Consequently, it seems possible that JNK activation was stimulated by ERK1/2.
In addition, because none of the inhibitors modified parthenolide effect on RIP-1 level (Figure 3a), stimulation of RIP-1 expression seemed to be independent of ROS production and activation of ERK1/2 and JNK.

Finally, also DMAPT increased the expression of p-JNK and RIP-1, as shown in Supplementary Figure 2SE.

\section{Parthenolide effects on caspases, c-FLIP and FADD.}

We also investigated by western blotting analysis whether parthenolide exerted some effects on the expression of pro-caspases and the production of their active forms (Figure 3b). Antibodies employed for this analysis detect both the full-length forms of caspases and the active fragments resulting from their cleavage. Parthenolide $(25 \mu \mathrm{M})$ decreased the levels of pro-caspases 3, 8 and 9 . The effect was observed already at $4 \mathrm{~h}$ and increased until $16 \mathrm{~h}$ of exposure. Interestingly, the cleaved and active forms of caspases were not detected also when the cells were exposed for $16 \mathrm{~h}$ to parthenolide.
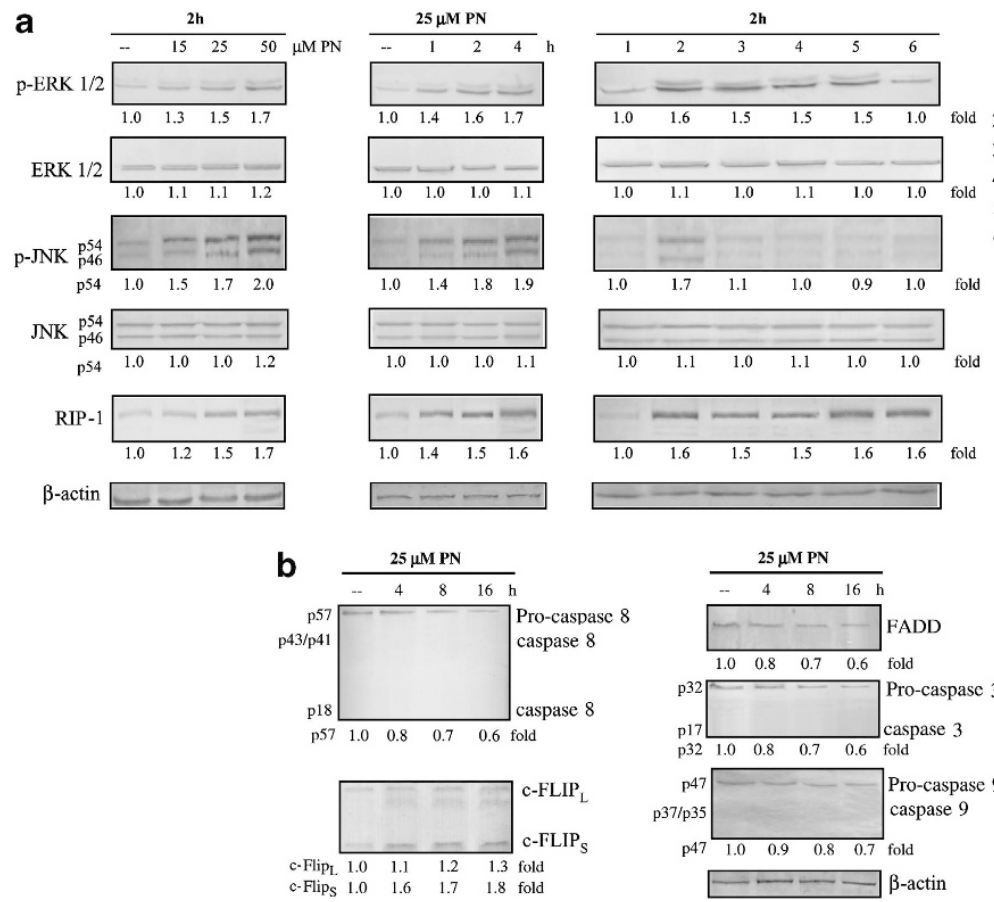

\section{1) CTR}

2) $25 \mu \mathrm{M} \mathrm{PN}$

3) $25 \mu \mathrm{M}$ PN +2 mM NAC

4) $25 \mu \mathrm{M} \mathrm{PN}+50 \mu \mathrm{M} \mathrm{SP} 600125$

5) $25 \mu \mathrm{M} \mathrm{PN}+100 \mu \mathrm{M}$ apocynin

6) $25 \mu \mathrm{M} \mathrm{PN}+20 \mu \mathrm{M} U 0126$

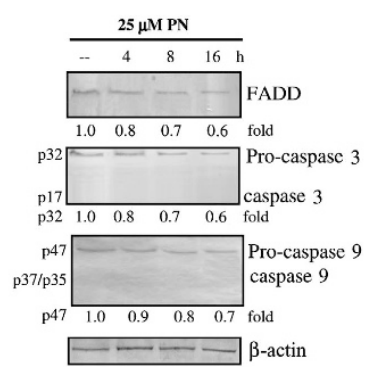

Figure 3 Western blotting analyses showing changes induced by parthenolide on the expression of various factors involved in the molecular mechanism of the drug. Cells $\left(2 \times 10^{5} \mathrm{cells} /\right.$ well $)$ were treated for different times and with various doses of parthenolide without or with various inhibitors. At the end, the extracts were prepared and submitted to western blotting analysis. (a) Parthenolide activates the expression of $p$-ERK1/2, p-JNK and RIP-1. (b) Changes induced by parthenolide on the levels of procaspase 8,3 and 9, c-FLIP and FADD. All the results are representative of three independent experiments

Figure 2 Parthenolide stimulates oxidative stress in MDA-MB231 cells. (a) Parthenolide induces production of superoxide anion. Cells $\left(8 \times 10^{3} /\right.$ well) were treated for $3 \mathrm{~h}$ with $25 \mu \mathrm{M}$ parthenolide alone or in the presence of $100 \mu \mathrm{M}$ apocynin or $10 \mu \mathrm{M}$ BAPTA-AM. At the end, after replacement of the culture medium with $100 \mu \mathrm{l}$ PBS, $20 \mu \mathrm{M}$ DHE was added and the incubation was protracted for $10 \mathrm{~min}$. Oxidation of DHE by superoxide anion generates red fluorescence, which was visualised with a Leica microscope at $\times 200$ magnification using a rhodamine filter. (b-e) Parthenolide induces ROS generation. Cells $\left(8 \times 10^{3}\right)$ were treated for various times with $15 \mu \mathrm{M}$ parthenolide alone or in the presence of various inhibitors. At the end, the medium was removed, $100 \mu \mathrm{l}$ of $50 \mu \mathrm{M} \mathrm{H}_{2}$-DCFDA were added and the incubation was protracted for 30 min at $37^{\circ} \mathrm{C}$. Then the fluorochrome was substituted with $100 \mu \mathrm{l}$ PBS and the analysis was performed after $20 \mathrm{~min}$. Oxidation of the fluorochrome produces green fluorescence, which was visualised with a Leica microscope equipped with a DC300F camera at $\times 200$ magnification using a FITC filter. (b) Images of fluorescence microscopy showing ROS generation induced by parthenolide at various times of treatment and (c) the relative percentages of cells with green fluorescence. (d) Images of fluorescence microscopy showing the influence of various inhibitors on ROS generation induced by treatment for 1 and $8 \mathrm{~h}$ with parthenolide and (e) the relative percentages of cells with green fluorescence. In (a, b and $\mathbf{d})$, the results are representative of three independent experiments. Scale bar, $10 \mu \mathrm{m}$. In (c) and (e) values are the means of three independent experiments $\pm S . E .{ }^{*} P<0.01$ versus untreated control 
Moreover, parthenolide increased the expression of cellular FLICE-like inhibitory protein (c-FLIP). This effect was much higher for $\mathrm{C}-\mathrm{FLIP}$ 的 $\mathrm{C}$-FLIP $\mathrm{P}_{\mathrm{L}}$, and was observed from 4 until $16 \mathrm{~h}$ of exposure. Conversely, parthenolide lowered the level of Fas-associated death domain (FADD) from 4 to $16 \mathrm{~h}$ of exposure
(Figure 3b). Similar results for caspase 8, c-FLIP and FADD were found treating the cells with $25 \mu \mathrm{M}$ DMAPT (Supplementary Figure S2F).

Parthenolide causes depletion of intracellular thiols. The observation that parthenolide rapidly increased ROS
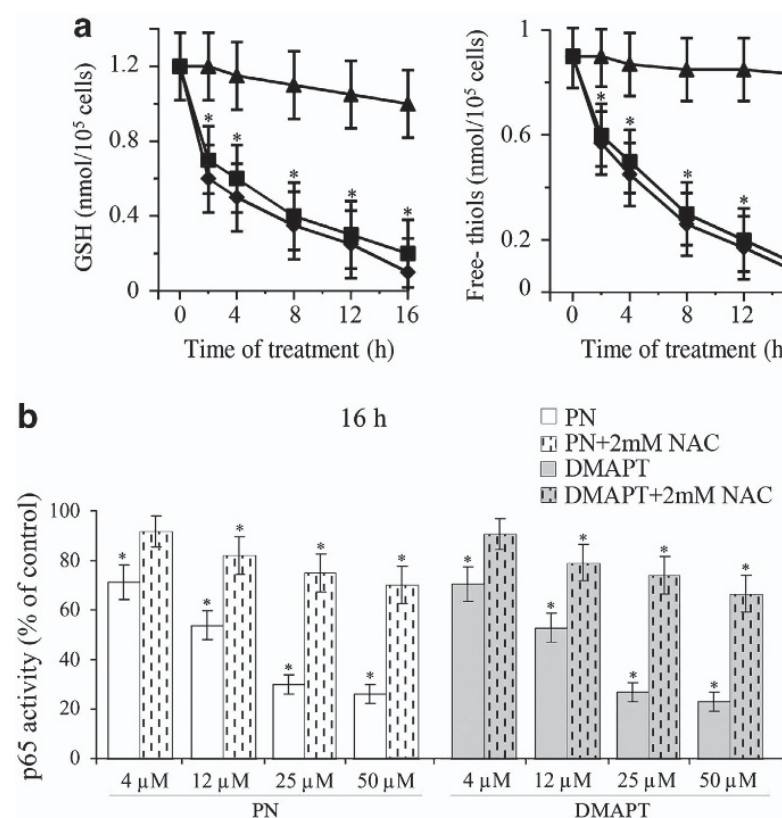

d

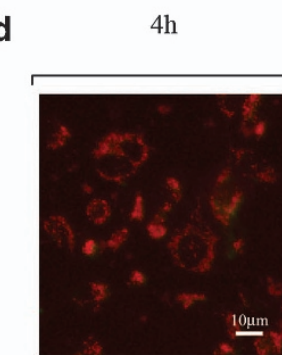

$8 \mathrm{~h}$

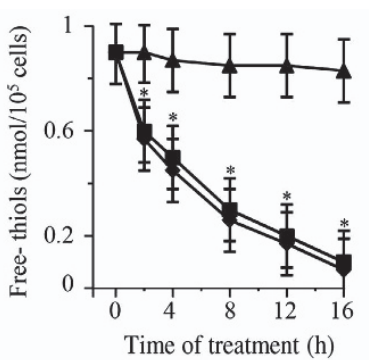

$\square \mathrm{PN}$

$\square$ DMAPT

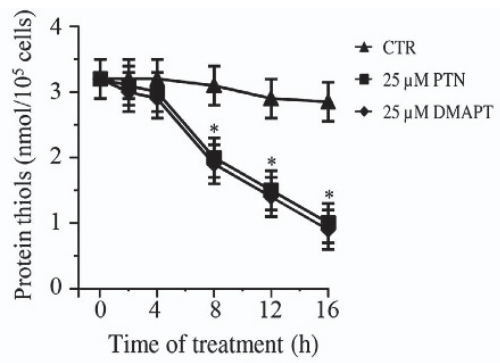

C

$16 \mathrm{~h}$

1) $\mathrm{CTR}$

2) $25 \mu \mathrm{M}$ PN

2) $25 \mu \mathrm{M} P \mathrm{PN}+2 \mathrm{mM}$ NAC

4) $25 \mu \mathrm{M}$ DMAPT

5) $25 \mu \mathrm{M}$ DMAPT $+2 \mathrm{mM} \mathrm{NAC}$
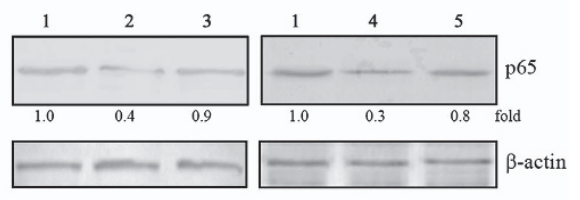

$16 \mathrm{~h}$

$16 \mathrm{~h}$ 2mM NAC
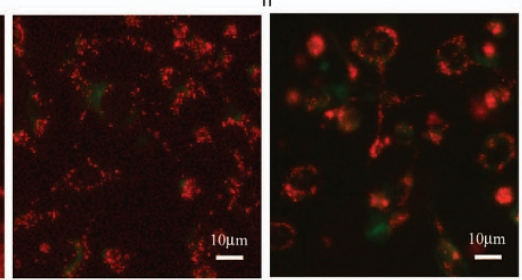

$25 \mu \mathrm{MPN}+2 \mathrm{mM}$ NAC
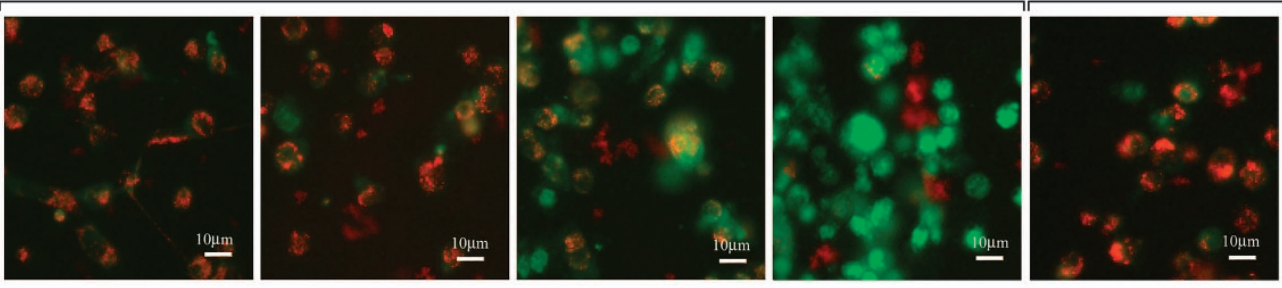

e

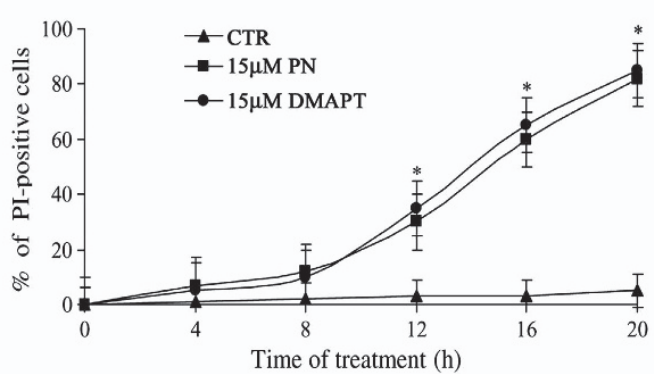

f

$16 \mathrm{~h}$

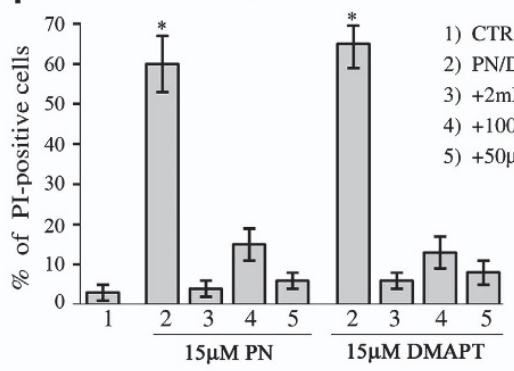


generation suggested to us that it can induce depletion of intracellular thiols.

As Figure 4a shows basal level of GSH exhibited a modest decrement in untreated cells during $16 \mathrm{~h}$ of incubation. Conversely exposure to $25 \mu \mathrm{M}$ parthenolide or DMAPT progressively lowered GSH level, which at $16 \mathrm{~h}$ fell in both the cases to only 10-15\% of control. Experiments were also performed to analyse the content of $\mathrm{SH}$ groups (free and protein thiols), revealing that the drugs decreased the content of free thiols similarly to GSH. Minor effects were observed for protein thiols, as their level was reduced at $16 \mathrm{~h}$ of treatment to about $30 \%$ of control both with parthenolide or DMAPT (Figure 4a).

Parthenolide effect on NF-kB activity. NF-kB is known to induce in tumour cells gene expression favouring survival, angiogenesis and metastasis. ${ }^{35}$ Therefore, targeting NF-kB represents a strategy in anticancer therapy, which might be effective particularly in TNBC cells, because the lack of oestrogen receptors might favour NF-kB activity. ${ }^{36}$

Interestingly, parthenolide inhibits NF-kB activity in many tumour cells, ${ }^{37,38}$ inducing cell death. We ascertained (Figure $4 \mathrm{~b}$ ) by ELISA assay that DNA-binding activity of p65, a subunit of NF-kB, decreased at $16 \mathrm{~h}$ of exposure to $4 \mu \mathrm{M}$ parthenolide or DMAPT by $25 \%$ and $30 \%$, respectively, while with both the drugs the highest decrement was observed using $50 \mu \mathrm{M}(-75 \%)$. NAC $(2 \mathrm{mM})$ partially prevented this effect, suggesting that ROS generated by parthenolide contributed to downregulate NF-kB activity.

Finally, treatment with $25 \mu \mathrm{M}$ parthenolide or DMAPT for $16 \mathrm{~h}$ reduced $\mathrm{p} 65$ protein level. Also this effect was prevented by $2 \mathrm{mM}$ NAC (Figure 4c).

Parthenolide causes dissipation of mitochondrial membrane potential and induces cell necrosis. We investigated whether $25 \mu \mathrm{M}$ parthenolide modified mitochondrial membrane potential $(\Delta \psi \mathrm{m})$ by using fluorescent cationic dye JC-1 (Figure 4d) and visualising fluorescence by a Leica microscope (Wetzlar, Germany). At $4 \mathrm{~h}$ of treatment, redorange fluorescence prevailed on greenish fluorescence, suggesting that most of cells were polarised. Then, greenish fluorescence increased with the time, reaching the maximum at $16 \mathrm{~h}$, when most of cells were depolarised. Dissipation of $\Delta \psi \mathrm{m}$ was suppressed by $2 \mathrm{mM}$ NAC.

To ascertain the effect of parthenolide and DMAPT on the induction of necrosis, cells were treated with $\mathrm{PI}$, a cell-impermeable nuclear dye, which stains the nuclei of cells that have lost plasma membrane integrity and are considered necrotic. With both the drugs $(15 \mu \mathrm{M})$, the percentage of $\mathrm{Pl}$-positive cells increased with the time of treatment at first slowly until $8 \mathrm{~h}$, when only a $15 \%$ of PI-positive cells was counted, then, more rapidly between $8-20 \mathrm{~h}$, reaching at $20 \mathrm{~h}$ a level of about $80 \%$ (Figure $4 \mathrm{e}$ ). This effect was suppressed by both NAC and Nec-1 (Figure 4f), suggesting that ROS generation and RIP-1 activation exerted a central role in the induction of cell necrosis.

Parthenolide induces autophagic process. Treatment with $15 \mu \mathrm{M}$ parthenolide produced autophagic vacuoles in the cytoplasm of MDA-MB231 cells. Vacuoles were visualised under fluorescence microscopy by staining with monodansylcadaverine (MDC) as distinct dot-like structures. ${ }^{39}$ As Figures $5 a$ and $b$ show about $65 \%$ of cells were positive to MDC test at $1 \mathrm{~h}$ of treatment. Then the effect increased up to $8 \mathrm{~h}$, when positive cells reached $80 \%$.

As above reported, parthenolide upregulated both p-JNK and RIP-1 expression. As both SP600125 and Nec-1, which inhibit activation of JNK and RIP-1 respectively, strongly reduced the number of MDC-positive cells (Figure $5 \mathrm{c}$ ), we suggest that parthenolide effect on autophagy was mediated by JNK and RIP-1. Moreover, also PI3K was needed for the production of autophagic vacuoles as both 3-methyladenine (3-MA) and wortmannin (PI3K inhibitors) reduced the number of MDC-positive cells (Figure 5c).

Microtubule-associated protein light chain 3 (LC3) is detected as two bands following SDS-PAGE: LC3-I, a cytosolic form, and LC3-II, a form conjugated with phosphatidylethanolamine present in autophagosomes. ${ }^{40}$ Parthenolide increased LC3-II level with a dose-dependent effect, which was highest at $2 \mathrm{~h}$ of treatment. Moreover, the effect was prevented by NAC and 3-MA and partially reduced by SP600125 and Nec-1 (Figure $5 d$ ).

Beclin-1 has an essential role in autophagosome formation. Its expression enhances during autophagy. However, its function is inhibited by interaction with $\mathrm{Bcl}-2$. Phosphorylation of $\mathrm{Bcl}-2$ by $\mathrm{JNK}^{41}$ causes the release of beclin- $1,{ }^{42}$ which can exert its pro-autophagic role. Parthenolide treatment increased beclin-1 expression with a dose-dependent effect, which reached the maximum at $2 \mathrm{~h}$ and was suppressed by NAC, SP600125 and Nec-1 and partially reduced by 3-MA (Figure $5 d$ ). Treatment with DMAPT produced similar effects on the expression of both LC3 and beclin-1 (Supplementary Figure S2E).

Figure 4 (a) Parthenolide and DMAPT induce depletion of intracellular GSH and thiols. Cells $\left(5 \times 10^{5} /\right.$ condition) were treated for various times with $25 \mu \mathrm{M}$ parthenolide or $25 \mu \mathrm{M}$ DMAPT. At the end, GSH, free thiols and protein thiols were determined using colorimetric assays, as reported in Materials and Methods. Values are expressed as $\mathrm{nmol} / 10^{5}$ cells. (b and $\mathbf{c}$ ) The effects of parthenolide and DMAPT on NF-kB activity. (b) The drugs downregulated DNA-binding activity of p 65 . Cells $\left(3 \times 10^{5} / \mathrm{condition}\right)$ were treated for $16 \mathrm{~h}$ with various concentrations of parthenolide or DMAPT without or with $2 \mathrm{mM} \mathrm{NAC}$. The binding was quantified in nuclear extracts by an ELISA assay as reported in Materials and Methods. (c) Western blotting analysis showing the effect of $25 \mu \mathrm{M}$ parthenolide and DMAPT on the expression of p65 protein. Cells (2×105/condition) were treated for $16 \mathrm{~h}$ with the drugs, without or with $2 \mathrm{mM} \mathrm{NAC}$. Cell lysates were prepared and subjected to western blotting as reported in Materials and Methods. (d) Parthenolide induces mitochondrial depolarisation in MDA-MB231 cells. Cells $\left(8 \times 10^{3} /\right.$ well) were treated for various times with $25 \mu \mathrm{M}$ parthenolide. After exposure, the fluorochrome JC-1 was added for additional $15 \mathrm{~min}$. Depolarisation was indicated by the shift of fluorescence from red-orange to greenish. Merged images were visualised with a Leica microscope at $\times 200$ magnification with fluorescent filters for FITC and rhodamine. Scale bar, $10 \mu \mathrm{m}$. The effect of parthenolide was prevented by $2 \mathrm{mM}$ NAC. (e and f) Parthenolide and DMAPT increased PI-positive cells. (e) Time course of the effect induced by $15 \mu \mathrm{M}$ parthenolide and DMAPT. (f) Influence of various inhibitors on the production of PI-positive cells induced by $15 \mu \mathrm{M}$ parthenolide or DMAPT for $16 \mathrm{~h}$. After treatment, the cells $\left(8 \times 10^{3} \mathrm{cells} / \mathrm{well}\right)$ were incubated for $15 \mathrm{~min}$ with PI $(2.0 \mu \mathrm{g} / \mathrm{ml}$ medium; red fluorescence) and the percentage of PI-positive cells was ascertained as described in Materials and Methods. In (a, b, e and $\mathbf{f})$ values are the means of three independent experiments \pm S.E. ${ }^{*} P<0.01$ versus untreated control. In (c) and (d) the results are representative of three independent experiments 

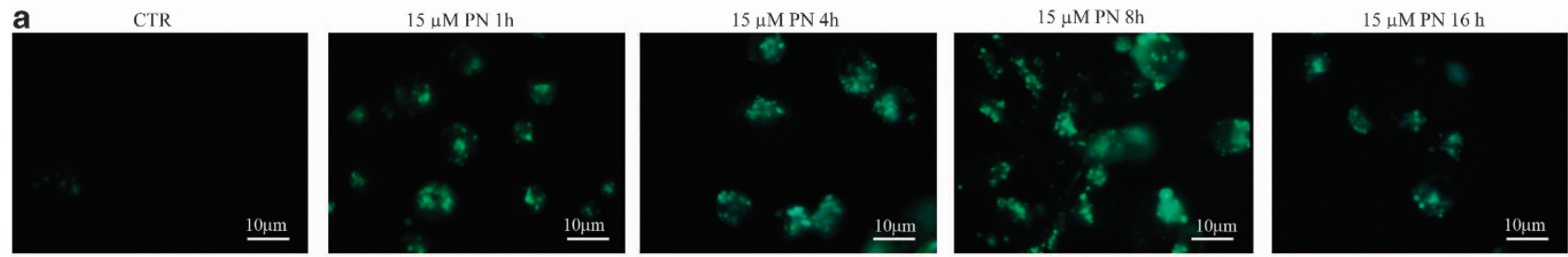

b
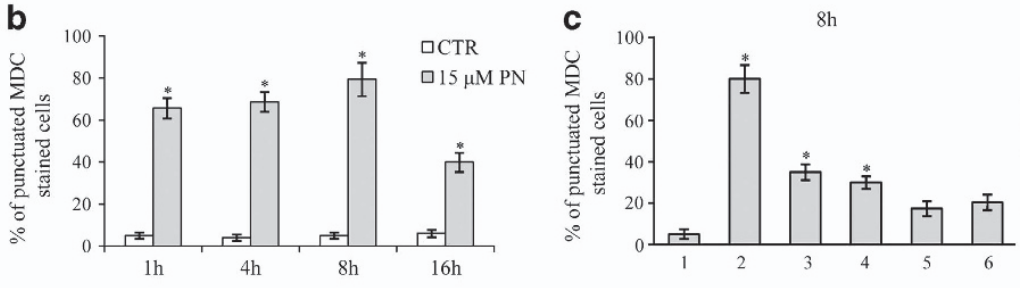

1) CTR

2) $15 \mu \mathrm{M} \mathrm{PN}$

3) $15 \mu \mathrm{M} \mathrm{PN}+5 \mathrm{mM} 3 \mathrm{MA}$

4) $15 \mu \mathrm{M} \mathrm{PN}+2 \mu \mathrm{M}$ Wortmannin

5) $15 \mu \mathrm{M} \mathrm{PN}+50 \mu \mathrm{M} \mathrm{SP} 600125$

6) $15 \mu \mathrm{M} \mathrm{PN}+50 \mu \mathrm{M} \mathrm{Nec}-1$ d

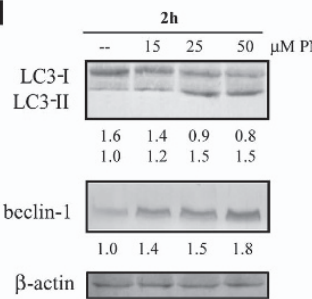

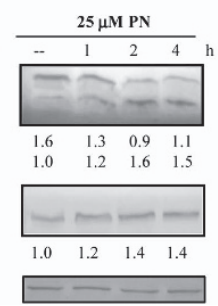

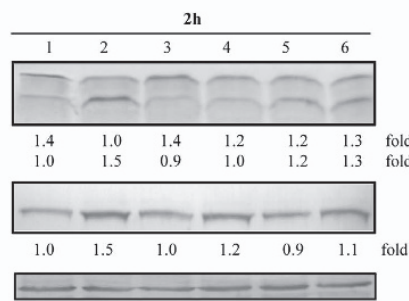

1) CTR

2) $25 \mu \mathrm{M} \mathrm{PN}$

3) $25 \mu \mathrm{M} \mathrm{PN}+2 \mathrm{mM} \mathrm{NAC}$

4) $25 \mu \mathrm{M} P \mathrm{~N}+5 \mathrm{mM} 3 \mathrm{MA}$

5) $25 \mu \mathrm{M} \mathrm{PN}+50 \mu \mathrm{M} \mathrm{SP} 600125$

6) $25 \mu \mathrm{M} \mathrm{PN}+50 \mu \mathrm{M} \mathrm{Nec}-1$

Figure 5 Parthenolide stimulates autophagic process in MDA-MB231 cells. (a-c) Detection of autophagic vacuoles with MDC test. Cells $\left(8 \times 10^{3}\right.$ cells/well) were treated for various times with $15 \mu \mathrm{M}$ parthenolide with or without inhibitors. At the end, the cells were incubated with $50 \mu \mathrm{M} \mathrm{MDC}$ for 10 min. Cell morphology was visualised with a Leica microscope with fluorescence filter for DAPI. MDC-labelled autophagic vacuoles appear as distinct dot-like structures distributed in the cytoplasm. (a) Fluorescent images showing positivity to MDC test at various times of treatment. At least five areas were scanned for each well and characteristic images for each condition are shown. Micrographs were acquired at a magnification of $\times 400$. Scale bar, $10 \mu \mathrm{m}$. (b) Quantification of the percentage of punctuated MDC stained cells measured at various times of exposure to parthenolide. (c) The influence of various inhibitors on the positivity to MDC test. (d) Western blotting analysis showing that parthenolide favoured conversion of LC3-I to LC3-II and increased the level of beclin-1. In (a) and (d), the results are representative of three independent experiments. In (b) and (c), values are the means of three independent experiments \pm S.E. ${ }^{*} P<0.01$ versus untreated control

Anticancer activity of DMAPT in a xenograft model of breast cancer. At first, a scratch assay in cell monolayer was performed to study DMAPT $(25 \mu \mathrm{M})$ effect on migration of MDA-MB231 cells in vitro. Wound closure was measured at various times and expressed as percentage of closure area. The untreated MDA-MB231 cells exhibited already at $4 \mathrm{~h}$ a rapid wound closure activity completely healing the scratched area at $16 \mathrm{~h}$ of incubation. This activity was instead hampered in DMAPT-treated cells, which showed a significant delay in wound healing (Figures 6a and b).

To ascertain whether $25 \mu \mathrm{M}$ DMAPT can affect epithelialmesenchymal transition, we examined DMAPT effect on vimentin level, a widely used mesenchymal marker. Untreated MDA-MB231 cells expressed a high level of vimentin, which was lowered by DMAPT treatment by $60 \%$ and $78 \%$ at 4 and $8 \mathrm{~h}$, respectively (Figure $6 \mathrm{c}$ ).

To demonstrate the effectiveness in vivo of DMAPT on breast cancer we implanted xenografts of MDA-MB231 cells in nude mice. When tumours became palpable with a size of $200 \mathrm{~mm}^{3}$, mice were randomised into two groups of 10 animals each. The treated group received daily DMAPT $(50 \mathrm{mg} / \mathrm{Kg})$, solubilised in ethanol, by oral gavage, while the untreated group received daily ethanol alone. DMAPT treatment markedly reduced tumour volume by $40.3 \%$ on day 7 and $48.3 \%$ on day 15 , when compared with tumours of the untreated group (Figure 7a). Long-term administration of DMAPT was well tolerated in mice. No sign of toxicity was apparent, such as weight loss or organ toxicity upon gross examination. In particular, histological analyses revealed the lack of abnormalities in liver, oesophagus and kidney of treated mice. Moreover, the Kaplan-Meier survival curve (Figure 7b) showed a significant increase in the median survival time which enhanced from 12 days for the control mice to 28 days.

Immunohistochemical analyses were performed using sections of tumours removed from mice of both the groups on days 16, 20 and 24 of treatment. Analyses conducted on sections of tumours removed on 16th day are reported in Figure 7c. Quantitative analyses (Figure 7d) performed by an image analysing system ${ }^{43}$ demonstrated that DMAPT treatment markedly reduced the level of VEGF, which is involved in tumour angiogenesis, and that of MMP-2 and MMP-9, two modulators of extracellular matrix remodelling. Finally, in line with the results found in cultured cells, p65 level decreased by DMAPT treatment, while $p$-JNK level markedly enhanced.

To ascertain DMAPT effectiveness in reducing lung metastasis, investigations were performed on mice of both the groups, killed on 16, 20 and 24 days of treatment. The relative area of lung metastasis was calculated using an image analysing system. The analyses for mice killed on 16th day of treatment (Figure 7e) showed that in treated mice about $5.7 \pm 0.5 \%$ of the lung area was replaced with cancer, while in the controls this area was equal to $17.0 \pm 0.9 \%$. 
a
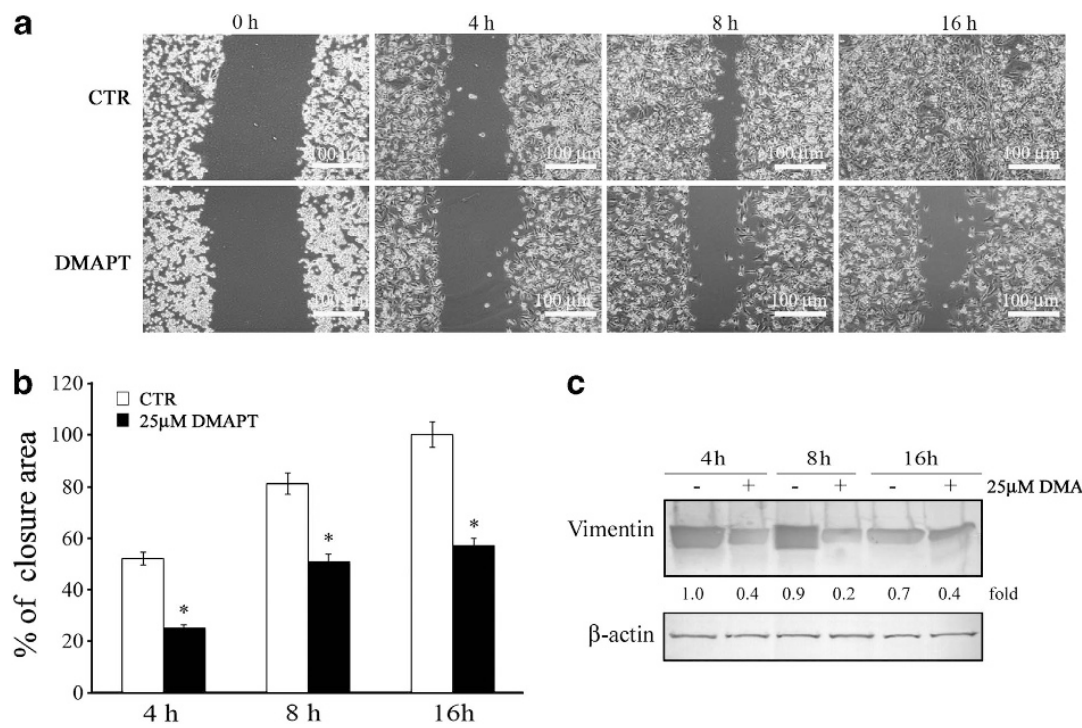

C

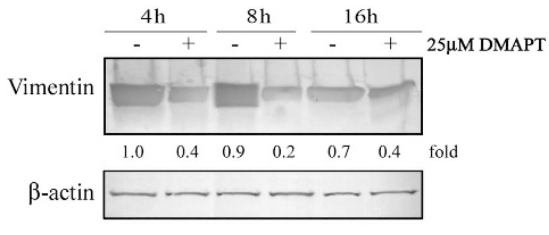

Figure 6 DMAPT inhibits MDA-MB231 cell motility. (a-b) Cells grown in monolayer were scratched with a pipet tip and then treated with $25 \mu$ M DMAPT. Cell motility was assessed by light microscopy and micrographs were taken at 4, 8 and $16 \mathrm{~h}$, respectively. (a) Representative images of the scratch wound area were taken immediately after wounding and at the indicated times. Scale bar, $100 \mu \mathrm{m}$. (b) The histogram represents the percentage of wound closure. The scratched area was determined by Image $\mathrm{J}$ software as described in Materials and Methods. Data are presented as the percentage of area populated by cells between 4 and $16 \mathrm{~h}$. (c) DMAPT lowered the level of mesenchymal marker vimentin. Cells were treated for 4, 8 and $16 \mathrm{~h}$ with $25 \mu \mathrm{M}$ DMAPT, then cell lysates were prepared and subjected to western blotting as reported in Materials and Methods. In (a) and (c), the results are representative of three independent experiments. In (b), values are the means of three independent experiments \pm S.E. ${ }^{*} P<0.01$ versus untreated control

\section{Discussion}

This paper investigates about the molecular mechanisms by which parthenolide and its soluble analogue DMAPT reduced in vitro viability of MDA-MB231 cells, which are hormoneinsensitive human breast cancer cells. Furthermore, we ascertained the effect in vivo of DMAPT on tumour xenografts derived from MDA-MB231 cells.

We employed in general $25 \mu \mathrm{M}$ parthenolide or DMAPT for in vitro experiments, except for experiments concerning $\mathrm{Ca}^{2+}$ level, ROS generation, MDC and PI tests, when $15 \mu \mathrm{M}$ was employed for both the drugs, because in these cases the lower concentration permitted to better appreciate the differences between the various conditions tested.

We demonstrate that parthenolide stimulated ROS generation, autophagic process and cell necrosis. ROS generation was higher in the first hours of treatment, when the drug induced superoxide anion production by stimulating NOX activity, an effect which was suppressed by apocynin, a specific inhibitor of NOX. Our observation agrees with the finding of Sun et al., ${ }^{26}$ showing that parthenolide activates NOX in prostate cancer cells. Moreover, as BAPTA-AM, an intracellular calcium chelator, prevented production of superoxide anion by parthenolide, we suggest that enhancement of cytosolic $\mathrm{Ca}^{2+}$ was required for NOX stimulation. Parthenolide itself most likely enhanced cytosolic $\mathrm{Ca}^{2+}$ level, because it behaves as a SERCA inhibitor. ${ }^{44}$ Finally, $\mathrm{Ca}^{2+}$ could stimulate NOX favouring activation of RAC-1 $1^{45}$ and its consequent migration from the cytoplasm to the membrane where it induces assembly of various NOX subunits. Moreover, parthenolide stimulated RIP-1 expression, another event involved in the activation of NOX-1. ${ }^{46}$
ROS generation induced by parthenolide caused two important consequences: (1) activation of JNK, an effect prevented by inhibitors of ROS generation, such as NAC and apocynin; (2) a marked decrement in DNA-binding activity of p65 with the consequent reduction of activity of NF-kB, a transcription factor that supports tumour cell viability.

After the first hours of treatment, ROS level declined until $16 \mathrm{~h}$. In the second phase, ROS partially derived by dysfunction of mitochondrial activity, as suggested by the finding that Rotenone and FCCP inhibited ROS generation at $8 \mathrm{~h}$.

ROS production induced by parthenolide stimulated autophagic process already at the first hours of exposure. This conclusion was suggested by the findings that the antioxidant NAC prevented the cells from the increment in beclin-1 expression and the conversion of LC3-I to LC3-II. It seems that ROS are essential for autophagy as they regulate Atg4, a cysteine protease involved in the process. ${ }^{47}$ Moreover, JNK and RIP-1 exerted a stimulatory role in this process, as their specific inhibitors SP600125 and Nec-1 prevented both positivity to MDC test and enhancement in LC3-II level. These findings are in accordance with the observation that JNK upregulates beclin- $1^{41}$ and favours its release from $\mathrm{Bcl}-2^{42}$, while RIP-1 increases LC3-II. ${ }^{48}$ Finally, as 3-MA and wortmannin, two inhibitors of PI3K, prevented autophagic process induced by parthenolide, we suggested that also $\mathrm{PI} 3 \mathrm{~K}$ is involved in the stimulation of autophagy.

An important consequence of the enhanced and persistent production of ROS was a remarkable decrement in the levels of both free thiols and free GSH, which fell at $16 \mathrm{~h}$ to very low values. GSH depletion could be responsible for mitochondrial depolarisation observed already after $12 \mathrm{~h}$ of treatment by 

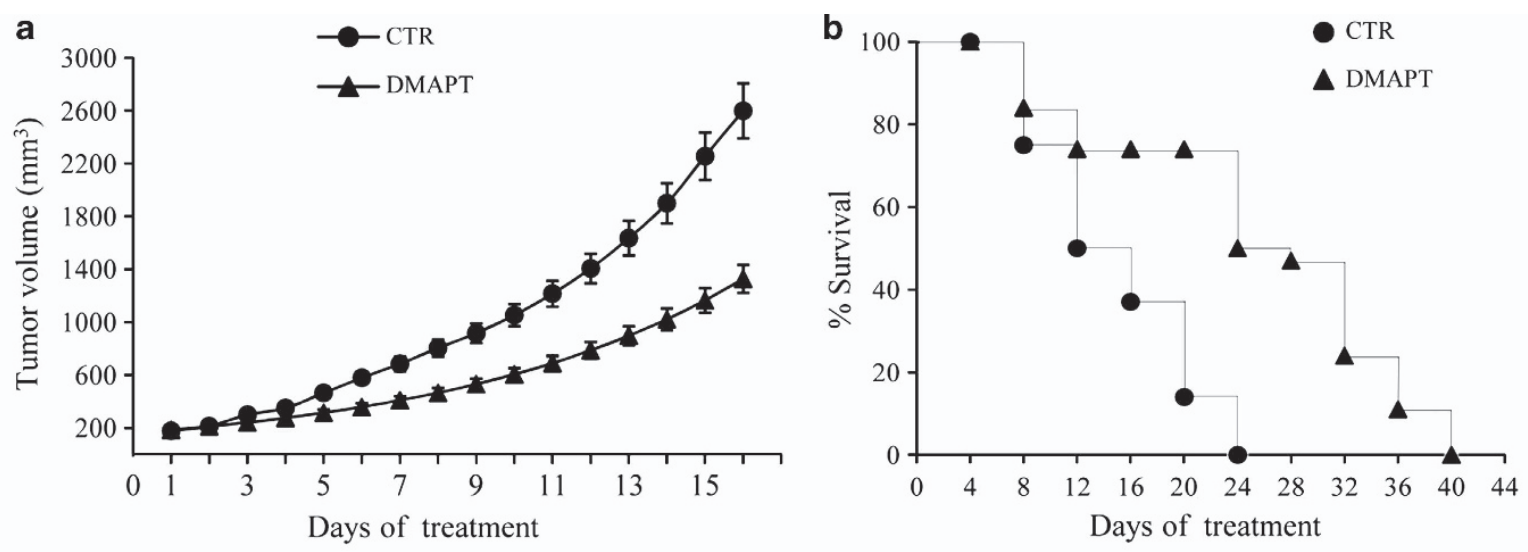

C VEGF MMP-2 MMP-9
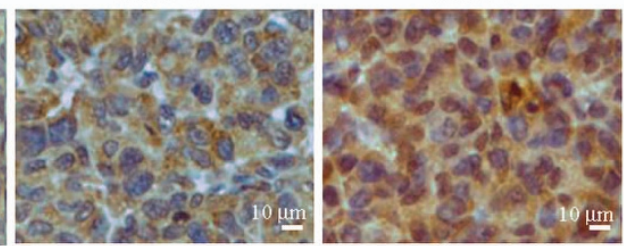

p65

p-JNK

CTR
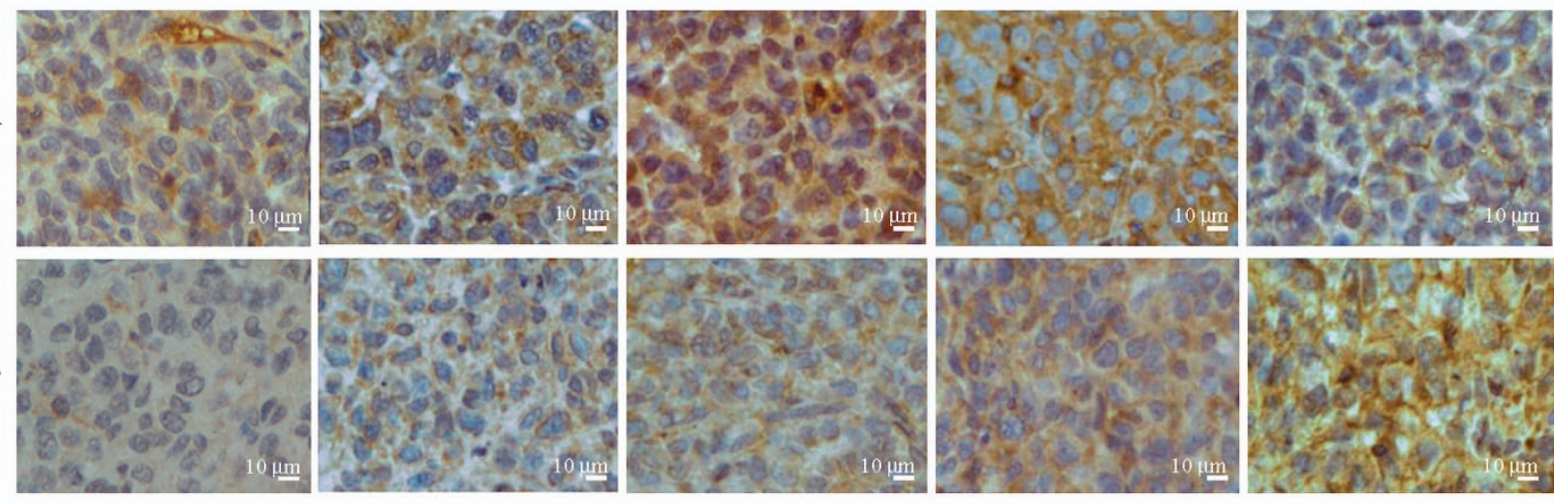

DMAPT

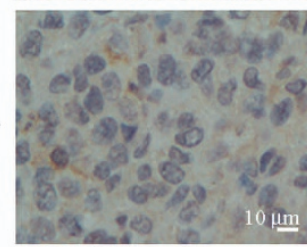

MMP-2

MMP-9
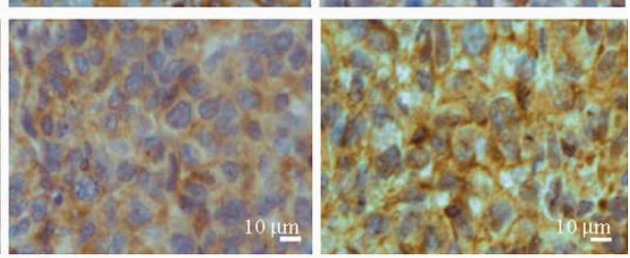

d

VEGF
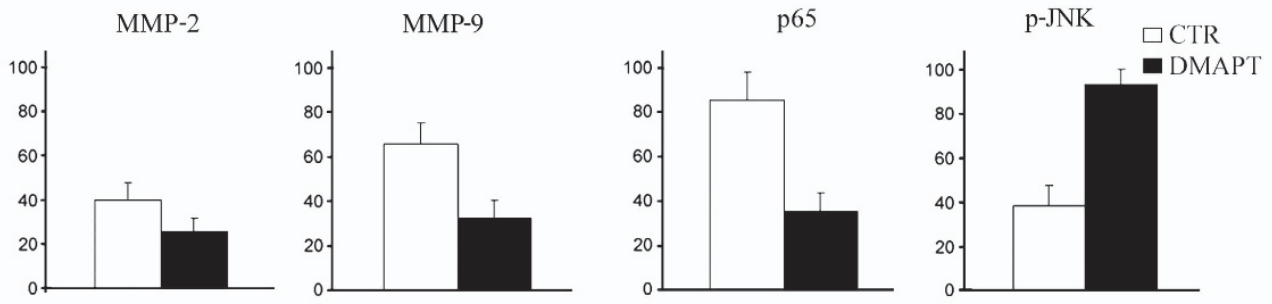

e

CTR

\section{DMAPT}
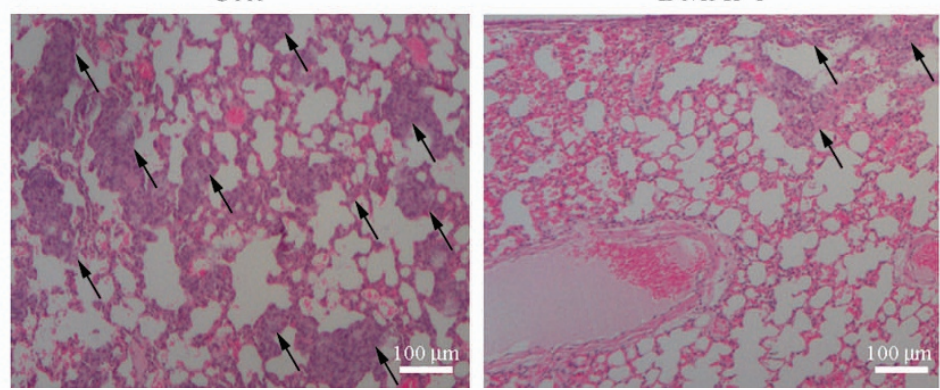

Figure 7 The effect of DMAPT on xenograft models of breast cancer. (a) The effect of DMAPT on tumor growth. After 8 days of tumour establishment, mice $(n=10)$ were treated by oral gavage with DMAPT $50 \mathrm{mg} / \mathrm{Kg} /$ daily. Progression profile of tumour growth was compared with that of control mice treated with vehicle alone. (b) Kaplan-Meier analysis. Mice treated with DMAPT showed prolonged survival when compared with mice treated with vehicle alone. (c) Immunohistochemical staining for VEGF, MMP-2, MMP-9, p65, p-JNK in MDA-MB231 xenografts. Tumours were examined at day 16 after treatment initiation. Original magnification $\times 400$. Scale bar, $10 \mu$ m. (d) Quantitative data showed that the level of VEGF, MMP-2, MMP-9 and p65 were decreased after DMAPT treatment, while the level of p-JNK was increased. (e) Metastasis in untreated and DMAPT-treated animals. Haematoxylin and eosin staining of lungs of control and treated mice at 16 days of treatment, showing that metastasis was lower in DMAPT-treated mice compared with untreated animals. Lung metastasis were indicated by solid arrows. Scale bar, $100 \mu \mathrm{m}$. In (c) and (e), the results are representative of three independent experiments. In (d), values are the means of three independent experiments \pm S.E. 
analysis with the fluorescent dye JC-1. This conclusion agrees with the finding of Zhang et al. ${ }^{13}$ that ROS and GSH oxidation are involved in the control of $\Delta \psi \mathrm{m}$. As a close consequence of $\Delta \psi \mathrm{m}$ dissipation, mitochondrial function appeared compromised. Therefore, between $12-20 \mathrm{~h}$ of treatment the number of PI-positive cells rapidly increased, suggesting that necrotic events became predominant at this stage. In accordance with these considerations, addition of NAC abrogated both dissipation of $\Delta \psi \mathrm{m}$ and positivity to PI. Also Nec-1 markedly reduced positivity to PI, suggesting that the increment of RIP-1 has an important role in the induction of necrosis.

The increment of RIP-1 level was most likely caused by the decrement of its cleavage by caspase 8 . Parthenolide in fact decreased pro-caspase 8 level but the cleaved forms of caspase 8 were not observed until $16 \mathrm{~h}$ of exposure. Conversely, the drug markedly increased c-FLIPS level. These findings suggested, in accordance with Feoktistova et al. ${ }^{49}$ that the catalytic activity of the ripoptosome complex in RIP-1 cleavage was repressed

Figure 8 summarises the molecular mechanism by which parthenolide induced death of MDA-MB231 cells. Also DMAPT induces cytotoxic effects on MDA-MB231 cells through a similar mechanism. Therefore, as DMAPT is more soluble than parthenolide it was employed for in vivo experiments.

The present article shows that DMAPT in vivo markedly reduced the growth of xenografts derived from MDA-MB231 cells and significantly enhanced survival of treated mice, while no sign of toxicity were apparent. Immunohistochemical analyses showed that DMAPT increased in vivo p-JNK level, while decreased that of the NF-kB component p65, likewise to the effects found in vitro. Moreover, the treatment markedly lowered the levels of factors involved in angiogenesis (VEGF) and in the production of metastasis (MMP-2 and MMP-9). These results agree with the observation ${ }^{50}$ that the decrease in NF-kB activity downregulates both VEGF and metalloproteinases and consequently represents an obstacle to the production of metastasis. Finally, in line with the results reported by Sweeney et al. ${ }^{18}$ and with our observation that DMAPT hampered in vitro cell migration, we demonstrated that lung metastases were markedly diminished in DMAPTtreated mice.

Taken together, our results suggest that DMAPT can be a candidate for TNBC therapy.

Moreover, the effectiveness of parthenolide in vivo could be improved by using the fumarate salt of DMAPT, which exhibits a good solubility in water. $^{21}$ Finally, another strategy to improve the cytotoxic activity of parthenolide on breast cancer cells could consist in its combination with other compounds capable of sensitising the cells to parthenolide action.

\section{Materials and Methods}

Chemicals and reagents. Parthenolide was supplied by Sigma-Aldrich (Milan, Italy). Stock solution of parthenolide was prepared in dimethyl sulfoxide (DMSO) and diluted to final concentration in the culture medium. Final concentration of DMSO employed as vehicle never exceeded $0.04 \%$ and had no discernible effects on MDA-MB231 cells in comparison with the control.

All reagents were purchased from Sigma-Aldrich, except for benzyloxycarbonylVal-Ala-Asp (OMe)-fluoromethylketone (z-VAD-fmk), which was supplied from Promega (Milan, Italy).

Cell cultures. MDA-MB231 cells, obtained from 'Istituto Scientifico Tumori' (Genoa, Italy), were grown as monolayer in DMEM culture medium supplemented with $10 \%$ heat-inactivated foetal calf serum, $2 \mathrm{mM}$ glutamine and $1 \%$ non essential amino acids, at $37^{\circ} \mathrm{C}$ in a humidified atmosphere containing $5 \% \mathrm{CO}_{2}$. After plating on 96- or 6-well plates, cells were allowed to adhere overnight and then treated with chemicals or vehicle only.

Cell viability and cell death assays. Cell viability was ascertained by MTT method, a colorimetric assay for measuring the activity of mitochondrial dehydrogenases that reduce the tetrazolium dye, MTT, to formazan. For these experiments, cells $\left(8 \times 10^{3} /\right.$ well) were plated in $200 \mu$ l of DMEM in a 96-well plate and treated for various times with parthenolide or DMAPT and other compounds. At the end, $20 \mu \mathrm{l}$ of MTT solution (11 mg/ml in PBS) were added and incubation was protracted for another $2 \mathrm{~h}$. Then the plate was centrifuged at $120 \mathrm{~g}$ for $5 \mathrm{~min}$, $190 \mu$ l of medium were removed, while $100 \mu$ l of lysis buffer (20\% sodium dodecyl

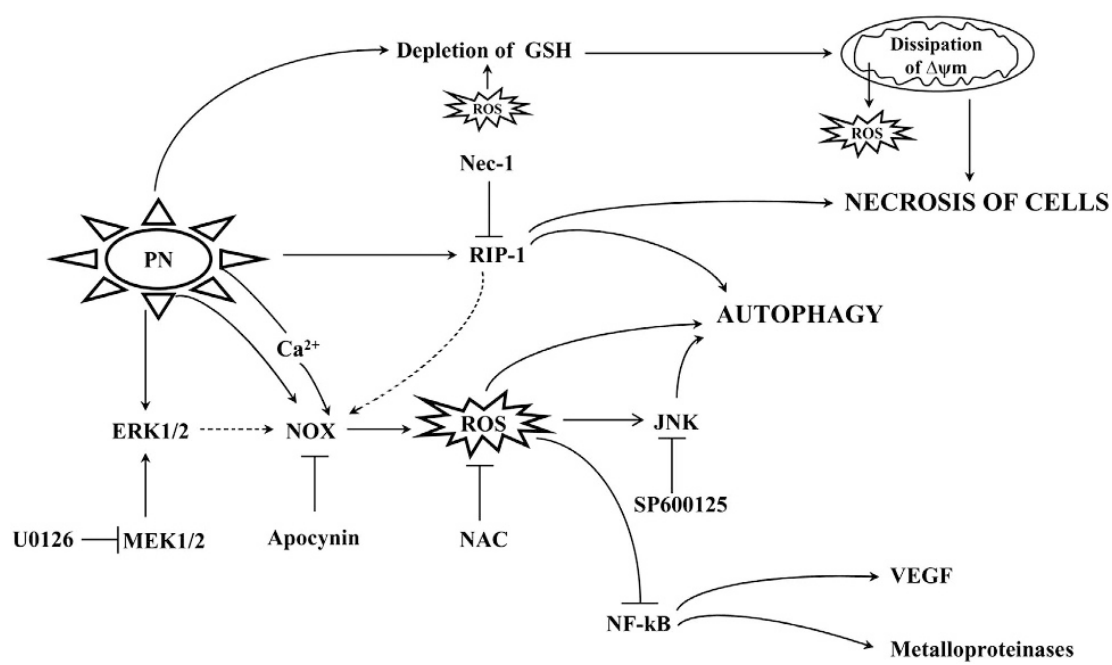

Figure 8 Schematic representation of parthenolide effect in MDA-MB231 cells. Parthenolide induces activation of NOX through a $\mathrm{Ca}^{2+}$-dependent mechanism, and also activation of ERK $1 / 2$ and RIP-1. All these events cause ROS production. ROS lead to activation of JNK and downregulation of NF-kB. Moreover, ROS, JNK and RIP-1 stimulate autophagic process. Persistent ROS generation induces GSH depletion and consequently dissipation of $\Delta \psi \mathrm{m}$ and cell necrosis 
sulphate in $50 \% \mathrm{~N}, \mathrm{~N}$-dimethylformamide) were added. The absorbance of the formazan was measured by a microplate reader (OPSYS MR, Dynex Technologies, Chantilly, VA, USA) at $540 \mathrm{~nm}$ with a reference wavelength of $630 \mathrm{~nm}$.

In order to determine extensive membrane damage, the cells were stained with $\mathrm{PI}$, as suggested by Asare et al. ${ }^{51}$ In particular, cells $\left(8 \times 10^{3} /\right.$ well) were incubated in culture medium and treated for various times with parthenolide or DMAPT and other compounds. Then PI ( $2.0 \mu \mathrm{g} / \mathrm{ml}$ medium) was added and the incubation was protracted for additional $15 \mathrm{~min}$. At the end, cell morphology was visualised by a Leica DMR microscope equipped with a DC300F camera (Wetzlar, Germany) using an appropriate filter to examine PI (rhodamine filter with excitation wavelength of $596 \mathrm{~nm}$ and emission wavelength of $620 \mathrm{~nm}$ ). All the images were acquired by Leica $Q$ Fluoro Software. Cells with red fluorescence were counted and normalised to total number of cells/field to calculate the percentage of PI-positive cells. Five fields/ condition were analysed.

Apoptotic and necrotic effects were studied by annexin $\mathrm{V}$ and $\mathrm{PI}$ co-staining using the Annexin V-FITC/PI Apoptosis Detection Kit I (BD Biosciences Pharmingen, San Diego, CA, USA), according to the manufacturer's instructions. Fluorescence of the cells $\left(10^{5}\right.$ per condition) was analysed by flow cytometry on a Beckman Coulter Epics XL flow cytometer (Brea, CA, USA).

Evaluation of ROS generation. Production of intracellular reactive oxygen intermediates was measured using 5-(and-6)-carboxy-2', $7^{\prime}$-dichlorodihydrofluorescein diacetate $\left(\mathrm{H}_{2}-\mathrm{DCFDA}\right)$, a fluorochrome that passively diffuses into cells. After cleavage of acetate groups by intracellular esterases, a fluorescent adduct is produced by oxidation. ${ }^{52}$

MDA-MB231 cells $\left(8 \times 10^{3} /\right.$ well) were incubated with parthenolide and other effectors for various times. At the end the medium was removed, $100 \mu \mathrm{l}$ of $50 \mu \mathrm{M}$ $\mathrm{H}_{2}$-DCFDA were added and incubation was protracted for $30 \mathrm{~min}$ at $37^{\circ} \mathrm{C}$. Then the medium was replaced with PBS and after 20 min the fluorescence was directly visualised by means of a fluorescence microscope using a FITC filter (excitation wavelength of $485 \mathrm{~nm}$ and emission wavelength of $530 \mathrm{~nm}$ ). Cells with green fluorescence were counted and normalised to total number of cells/field to calculate the percentage of cells producing ROS. Five fields/condition were analysed.

Measurement of superoxide production. The superoxide radical production was assessed by using DHE, a fluorochrome that is oxidised by superoxide to generate fluorescent ethidium that intercalates with nuclear DNA. ${ }^{53}$ MDA-MB231 cells $\left(8 \times 10^{3} /\right.$ well) were incubated with parthenolide or other effectors, then cells were centrifuged at $120 \mathrm{~g}$ for $5 \mathrm{~min}$ and culture medium was replaced with a solution of DHE $(20 \mu \mathrm{M})$ in PBS. The incubation was protracted for $10 \mathrm{~min}$ and DHE-positive cells were analysed by fluorescence microscopy using an excitation wavelength of $596 \mathrm{~nm}$ and an emission wavelength of $620 \mathrm{~nm}$. All the images were acquired by Leica $Q$ Fluoro Software.

Measurement of calcium level. Cytosolic calcium level was measured using Fluo-3AM ${ }^{13}$ as previously reported. ${ }^{19}$ Cells $\left(2 \times 10^{5} /\right.$ well) were collected, washed twice with cold calcium-free PBS and then incubated with $5 \mu \mathrm{M}$ Fluo-3AM for $60 \mathrm{~min}$ at $37^{\circ} \mathrm{C}$ in darkness. Then the cells were analysed by flow cytometry on a Beckman Coulter Epics XL flow cytometer using the Expo32 software (Beckman Coulter, Brea, CA, USA).

Detection of autophagic vacuoles. Autophagic vacuoles were detected by $\mathrm{MDC}^{39,54}$ a phospholipidic-specific marker that selectively accumulates in autophagosomes, which appear as distinct dot-like structures. After exposure to parthenolide treatment, cells were incubated with MDC $(50 \mu \mathrm{M})$ in PBS at $37^{\circ} \mathrm{C}$ for $10 \mathrm{~min}$, then washed in PBS and immediately analysed by fluorescence microscopy by using DAPI filter (excitation wavelength of $372 \mathrm{~nm}$ and emission wavelength of $456 \mathrm{~nm}$ ). Micrographs were acquired by Leica $Q$ Fluoro Software.

Measurement of intracellular thiols and GSH content. To measure intracellular thiols, ${ }^{13}$ cells after the treatment were detached, washed in PBS and resuspended in $30 \mathrm{mM}$ Tris $\mathrm{HCl}, 3 \mathrm{mM}$ EDTA, pH 8.2. For determination of protein

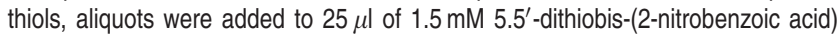
(DTNB, Ellman's reagent) and $400 \mu$ l methanol. After centrifugation at $3000 \mathrm{~g}$ for $5 \mathrm{~min}, 250 \mu \mathrm{l}$ of each supernatant were transferred in a 96-well plate and read at $400 \mathrm{~nm}$. For the analysis of free thiol groups, aliquots were incubated with $25 \mu \mathrm{l}$ $10 \%$ trichloroacetic acid and centrifuged. Each supernatant $(50 \mu \mathrm{l})$ was transferred in a 96-well plate in the presence of $200 \mu \mathrm{l} 0.2 \mathrm{M}$ Tris HCl, $\mathrm{pH} 8.9$ and $20 \mu \mathrm{l}$ DTNB.
Then the samples were read at $400 \mathrm{~nm}$. The absorbance was determined by an automatic ELISA plate reader. The final content of intracellular thiols was expressed as nanomoles of SH groups per $10^{5}$ cells.

The intracellular GSH content was measured using a commercial assay, provided by OXIS Research (Portland, OR, USA). After treatment, the cells $\left(5 \times 10^{5} /\right.$ condition) were harvested, and centrifuged at $120 \mathrm{~g}$ for $8 \mathrm{~min}$. The pellets were washed in PBS and resuspended in $50 \mu \mathrm{l}$ metaphosphoric acid $(5 \mathrm{~g} / 100 \mathrm{ml}$ distilled water) and centrifuged at $3000 \mathrm{~g}$ for $10 \mathrm{~min}$. GSH content was measured as described by manufacturer's instructions. Absorbance was read at $400 \mathrm{~nm}$ in a 96-well plate reader. The content of intracellular GSH was expressed as nanomoles of GSH per $10^{5}$ cells.

Measurement of NF-kB activity. NF-kB activity was evaluated by an ELISA-based assay (Trans-AM NF-kB; Active Motif, Carlsbad, CA, USA) as described by manufacturer's protocol. Briefly, nuclear extracts were prepared as previously reported ${ }^{55}$ using $3 \times 10^{5}$ cells/condition. Aliquots were placed in 96 -well plates coated with an oligonucleotide containing the NF-kB consensus sequence. NF-kB activity was detected using a specific antibody for p65 subunit provided by the kit.

Analysis of mitochondrial membrane potential. In order to study the effect of parthenolide on mitochondrial membrane potential $(\Delta \psi \mathrm{m}), \mathrm{MDA}-\mathrm{MB} 231$ cells $\left(8 \times 10^{3} /\right.$ well), after exposure to compounds, were treated for additional 15 min with JC- 1 staining solution ${ }^{56}$ and $\Delta \psi m$ was evaluated as indicated in the manufacturer's protocol supplied by the Cayman Chemical Company (Ann Arbour, MI, USA). Cells were visualised by a fluorescence microscope. Healthy cells with polarised mitochondria were detected using an appropriate filter to examine J-aggregates with red-orange fluorescence (rhodamine filter with excitation wavelength of $596 \mathrm{~nm}$ and emission wavelength of $620 \mathrm{~nm}$ ). Unhealthy cells were detected using a filter to examine JC-1 monomers with green fluorescence (FITC filter with excitation wavelength of $485 \mathrm{~nm}$ and emission wavelength of $530 \mathrm{~nm}$ ).

For all determinations, fluorescence was visualised by means of a Leica DMR microscope equipped with a DC300F camera (Wetzlar, Germany), using the Leica Q Fluoro Software.

Western blotting analysis. Whole-cell lysates were prepared as previously reported ${ }^{57}$ and protein concentration was determined by Lowry assay. ${ }^{58}$ Protein samples (50 $\mu \mathrm{g} / \mathrm{lane}$ ) were subjected to SDS polyacrylamide gel electrophoresis, then transferred to a nitrocellulose membrane.

All western blotting analyses were performed using specific antibodies obtained by Santa Cruz Biotechnology (Santa Cruz, CA, USA), except for anti-RIP-1 antibody, which was provided by Abcam (San Francisco, CA, USA), anti-beclin-1, anti-caspase 3, 8 and 9 antibodies by Cell Signaling Technology (Beverly, MA, USA) and anti-LC3 antibody by Novus Biologicals (Cambridge, UK).

Then detection was developed using secondary antibodies conjugated with alkaline phosphatase.

Protein bands were visualised using 5-bromo-4-chloro-3-indolyl phosphate and nitro blue tetrazolium (Promega Italia) and their intensity was quantified by densitometric analysis using SMX Image software (Bio-Rad, Hercules, CA, USA).

The correct protein loading was ascertained by red Ponceau staining and immunoblotting for $\beta$-actin. All the blots shown are representative of at least three separate experiments.

Cell migration. Cell migration was studied by using an in vitro scratch assay. MDA-MB231 cells $\left(2 \times 10^{5} /\right.$ well) were seeded on 6 -well tissue culture plates and grown to $100 \%$ confluence. Wounds were created by scraping the monolayer of cells with a sterile pipette tip, washed with PBS to remove the floating cells and incubated with fresh medium in the presence or absence of DMAPT.

The images (five/field) of scratched area were captured (at $\times 100$ magnification) using a Leica DMR microscope equipped with DC300F digital camera immediately after wounding and at 4,8 and $16 \mathrm{~h}$ after application of DMAPT. The images were compared with estimate the effects of DMAPT on wound healing and the percentage of closure area was calculated by Image $\mathrm{J}$ software.

Animals and subcutaneous implantation of tumours. Female nude athymic mice (Fox1 nu/nu) aged 4 weeks were obtained from Harlan (Udine, Italy) and allowed to acclimatise for 1 week.

Suspensions of $2 \times 10^{6} \mathrm{MDA}-\mathrm{MB} 231$ cells in $0.2 \mathrm{ml}$ of PBS were inoculated into the mammary fat pad. Eight days after inoculation, when tumours became palpable, 
mice were subdivided into two groups of 10 animals each being the tumour volumes equally distributed between the two groups. One group of mice was treated daily with $50 \mathrm{mg} / \mathrm{Kg}$ DMAPT (Biomol, Plymouth Meeting, PA, USA) prepared in a solution at $50 \%$ ethanol, administered by oral gavage. Control group received daily by oral gavage vehicle alone. Tumour volumes were determined daily using calipers. Primary tumour volumes were calculated with the formula: $v=$ length $\times(\text { width })^{2} / 2$. Mice were euthanised when tumour burden exceeded $10 \%$ of the animal normal body weight, or when tumour ulcerates or other conditions of morbidity were ascertained, in conformity with institutional guidelines which are in compliance with national (D.L., 116 G.U., Suppl.40; 18 February 1992) and international laws and policies (ECC Council Directive 86/609, OJ L358.1, 12 December 1987). This study was authorised by Italian Ministry of Health.

Immunohistochemistry (IHC). Immunohistochemical studies were performed on formalin-fixed paraffin-embedded tumour tissues. Serial sections $(4 \mu \mathrm{m}$ thick) were fixed on glass slides, washed in xylen and hydrated in different (decreasing) concentrations of alcohol. For antigen retrieval the slides were heated in sodium citrate solution (pH 6.0) at $96^{\circ} \mathrm{C}$ for $20 \mathrm{~min}$. Endogenous peroxidase activity was quenched with $3 \%$ hydrogen peroxide in methanol for $30 \mathrm{~min}$. Then the slides were treated with $1 \%$ bovine serum albumin (BSA) for $30 \mathrm{~min}$ and incubated overnight at $4{ }^{\circ} \mathrm{C}$ in the presence of $0.1 \%$ BSA with one of the following antibodies: mouse monoclonal p-JNK (1:50), mouse monoclonal NF-kB (p65) $(1: 50)$, rabbit polyclonal MMP-2 $(1: 50)$, mouse monoclonal MMP-9 $(1: 50)$ and mouse monoclonal VEGF $(1: 50)$. All these antibodies were provided by Santa Cruz Biotechnology, except for VEGF antibody, which was provided by R\&D Systems (Minneapolis, MN, USA).

At the end, the sections were treated for 30 min with secondary biotinylated immunoglobulin anti-mouse, anti-rabbit and anti-goat antibody (DAKO, Glostrup, Denmark). Then the sections were incubated with the streptavidin conjugated to horseradish peroxidase for $1 \mathrm{~h}$, followed by the chromogen $3-3^{\prime}$ diamminobenzidine tetrahydrochloride for $1 \mathrm{~min}$, counterstained with Mayer's haematoxylin. Immunoreactivity of these antibodies was ascertained by means of the labelled streptavidinbiotin method (LSAB; Dako) according to manufacturer's instructions. All immunostained sections were analysed at a $\times 400$ magnification (five fields) under a Leica DMLB optical microscope. Digital images were then analysed by Image $\mathrm{J}$ computer program ${ }^{42}$ to evaluate the percentage of positive area for all antibodies used in immunohistochemistry analyses.

In order to study lung metastasis, lungs were removed from mice, after killing, fixed in formalin, embedded in paraffin and stained with haematoxylin and eosin. Three sections were obtained for each lung. The lung sections were examined at $\times 50$ magnification and compared with sections obtained from control mice. The percentage of positive area was analysed by NIS-Elements software (Nikon Instruments, Florence, Italy).

Statistical analysis. Results are presented as means \pm S.E. Data were analysed using Student's $t$-test.

\section{Conflict of Interest}

The authors declare no conflict of interest.

Acknowledgements. This work was partially funded by European Regional Development Fund, European Territorial Cooperation 2007-2013, CCI 2007 CB 163 PO 037, OP Italia-Malta 2007-2013. The research was also supported by Grants from: Italian Ministry of Education, University and Research (MIUR) ex-60\%, 2007; Innovative Research Projects, University of Palermo, Italy, 2007; Istituto Zooprofilattico Sperimentale della Sicilia 'A Mirri', Palermo, Italy. Dr D Carlisi is a recipient of a Grant by 'Italian Ministry of Education, University and Research' (MIUR). Dr R Martinez and S Di Bella are PhD students supported by 'Italian Ministry of Education, University and Research' (MIUR).

1. Dey N, Smith BR, Leyland-Jones B. Targeting basal-like breast cancers. Curr Drug Targets 2012; 13: 1510-1524.

2. Bauer KR, Brown M, Cress RD, Parise CA, Caggiano V. Descriptive analysis of estrogen receptor (ER)-negative, progesterone receptor (PR)-negative, and HER2-negative invasive breast cancer, the so-called triple-negative phenotype: a population-based study from the California Cancer Registry. Cancer 2007; 109: 1721-1728.
3. Bayraktar S, Glück S. Molecularly targeted therapies for metastatic triple-negative breast cancer. Breast Cancer Res Treat 2013; 138: 21-35.

4. Yagata $\mathrm{H}$, Kajiura $\mathrm{Y}$, Yamauchi $\mathrm{H}$. Current strategy for triple-negative breast cancer: appropriate combination of surgery, radiation, and chemotherapy. Breast Cancer 2011; 18: 165-173.

5. Hudis CA, Gianni L. Triple-negative breast cancer: an Unmet Medical Need. Oncologist 2011; 1: 1-11.

6. Oakman C, Moretti E, Galardi F, Biagioni C, Santarpi L, Biganzoli L et al. Adjuvant systemic treatment for individual patients with triple negative breast cancer. Breast 2011; 20: 135-141.

7. Liedtke C, Mazouni C, Hess KR, André F, Tordai A, Mejia JA et al. Response to neoadjuvant therapy and long-term survival in patients with triple negative breast cancer. J Clin Oncol 2008; 26: 1275-1281.

8. Dent R, Trudeau M, Pritchard KI, Hanna WM, Kahn HK, Sawka CA et al. A triple-negative breast cancer: clinical features and patterns of recurrence. Clin Cancer Res 2007; 13: 4429-4434.

9. Pogoda K, Niwińska A, Murawska M, Pieńkowski T. Analysis of pattern, time and risk factors influencing recurrence in triple-negative breast cancer patients. Med Oncol 2013; 30: 388 .

10. Mathema VB, Koh YS, Thakuri BC, Sillanpää M. Parthenolide, a sesquiterpene lactone, expresses multiple anti-cancer and anti-inflammatory activities. Inflammation 2012; 35: 560-565.

11. Hayashi S, Koshiba K, Hatashita M, Sato T, Jujo Y, Suzuki R et al. Thermosensitization and induction of apoptosis or cell-cycle arrest via the MAPK cascade by parthenolide, an $\mathrm{NF}-\mathrm{kB}$ inhibitor, in human prostate cancer androgen-independent cell lines. Int J Mol Med 2011; 28: 1033-1042

12. Liu JW, Cai MX, Xin Y, Wu QS, Ma J, Yang P et al. Parthenolide induces proliferation inhibition and apoptosis of pancreatic cancer cells in vitro. J Exp Clin Cancer Res 2010; 29 : 108

13. Zhang S, Ong CN, Shen HM. Critical roles of intracellular thiols and calcium in parthenolide-induced apoptosis in human colorectal cancer cells. Cancer Lett 2004; 208: 143-153.

14. Suvannasankha A, Crean CD, Shanmugam R, Farag SS, Abonour R, Boswell HS et al. Antimyeloma effects of a sesquiterpene lactone parthenolide. Clin Cancer Res 2008; 14: 1814-1822.

15. Zunino SJ, Ducore JM, Storms DH. Parthenolide induces significant apoptosis and production of reactive oxygen species in high-risk pre-B leukemia cells. Cancer Lett 2007; 254: 119-127.

16. Guzman ML, Rossi RM, Karnischky L, Li X, Peterson DR, Howard DS et al. The sesquiterpene lactone parthenolide induces apoptosis of human acute myelogenous leukemia stem and progenitor cells. Blood 2005; 105: 4163-4169.

17. Nakshatri H, Rice SE, Bhat-Nakshatri P. Antitumor agent parthenolide reverses resistance of breast cancer cells to tumour necrosis factor-related apoptosis-inducing ligand through sustained activation of c-Jun N-terminal kinase. Oncogene 2004; 23: 7330-7344.

18. Sweeney CJ, Mehrotra S, Sadaria MR, Kumar S, Shortle NH, Roman Y et al. The sesquiterpene lactone parthenolide in combination with docetaxel reduces metastasis and improves survival in a xenograft model of breast cancer. Mol Cancer Ther 2005; 4: 1004-1012.

19. D'Anneo A, Carlisi D, Lauricella M, Emanuele S, Vento R, Tesoriere G et al. Parthenolide induces caspase-independent and AIF-mediated cell death in human osteosarcoma and melanoma cells. J Cell Physiol 2013; 228: 952-967.

20. Curry EA III, Murry DJ, Yoder C, Fife K, Armstrong V, Nakshatrim H et al. Phase I dose escalation trial of feverfew with standardized doses of parthenolide in patients with cancer. Invest New Drugs 2004; 22: 299-305.

21. Guzman ML, Rossi RM, Neelakantan S, Li X, Corbett CA, Hassane DC. An orally bioavailable parthenolide analog selectively eradicates acute myelogenous leukemia stem and progenitor cells. Blood 2007; 110: 4427-4435.

22. Shanmugam R, Kusumanchi $P$, Cheng L, Crooks $P$, Neelakantan $S$, Matthews $W$ et al. A water-soluble parthenolide analogue suppresses in vivo prostate cancer growth by targeting NFkappaB and generating reactive oxygen species. Prostate 2010; 70: 1074-1086.

23. Shanmugam R, Kusumanchi $\mathrm{P}$, Appaiah $\mathrm{H}$, Cheng L, Crooks $\mathrm{P}$, Neelakantan $\mathrm{S}$ et al. A water soluble parthenolide analog suppresses in vivo tumor growth of two tobaccoassociated cancers, lung and bladder cancer, by targeting NF-kB and generating reactive oxygen species. Int J Cancer 2011; 128: 2481-2494.

24. Declercq W, Vanden Berghe T, Vandenabeele P. RIP kinases at the crossroads of cell death and survival. Cell 2009; 138: 229-232.

25. Sawai H, Domae N. Discrimination between primary necrosis and apoptosis by necrostatin1 in Annexin V-positive/propidium iodide-negative cells. Biochem Biophys Res Commun 2011; 411: 569-573.

26. Sun Y St, Clair DK, Xu Y, Crooks PA, St Clair WH. A NADPH oxidase-dependent redox signaling pathway mediates the selective radiosensitization effect of parthenolide in prostate cancer cells. Cancer Res 2010; 70: 2880-2890.

27. Wang W, Adachi M, Kawamura R, Sakamoto $H$, Hayashi $T$, Ishida $T$ et al. Parthenolide-induced apoptosis in multiple myeloma cells involves reactive oxygen species generation and cell sensitivity depends on catalase activity. Apoptosis 2006; 11 : 2225-2235. 
28. Wu F, Tyml K, Wilson JX. iNOS expression requires NADPH oxidase-dependent redox signaling in microvascular endothelial cells. J Cell Physiol 2008; 117: 207-214.

29. Ahmad A, Mondello S, Di Paola R, Mazzon E, Esposito E, Catania MA et al. Protective effect of apocynin, a NADPH-oxidase inhibitor, against contrast-induced nephropathy in the diabetic rats: a comparison with $\mathrm{N}$-acetylcysteine. Eur J Pharmacol 2012; 674: 397-406.

30. Tang Q, Jin MW, Xiang JZ, Dong MQ, Sun HY, Lau CP et al. The membrane permeable calcium chelator BAPTA-AM directly blocks human ether a-go-go-related gene potassium channels stably expressed in HEK 293 cells. Biochem Pharmacol 2007; 74: 1596-1607.

31. Dugan LL, Sensi SL, Canzoniero LM, Handran SD, Rothman SM, Lin TS et al. Mitochondrial production of reactive oxygen species in cortical neurons following exposure to N-methyl-D-aspartate. J Neurosci 1995; 15: 6377-6388.

32. Moon EJ, Sonveaux P, Porporato PE, Danhier P, Gallez B, Batinic-Haberle I et al. NADPH oxidase-mediated reactive oxygen species production activates hypoxia-inducible factor-1 (HIF-1) via the ERK pathway after hyperthermia treatment. Proc Natl Acad Sci USA 2010; 107: 20477-20482.

33. Kurdi M, Booz GW. Evidence that IL-6-type cytokine signaling in cardiomyocytes is inhibited by oxidative stress: parthenolide targets JAK1 activation by generating ROS. J Cell Physiol 2007; 212: 424-431.

34. Bennett BL, Sasaki DT, Murray BW, O'Leary EC, Sakata ST, Xu W et al. SP600125, an anthrapyrazolone inhibitor of Jun N-terminal kinase. Proc Natl Acad Sci USA 2001; 98 : 13681-13686.

35. Baldwin AS. Control of oncogenesis and cancer therapy resistance by the transcription factor NF-kappaB. J Clin Invest 2001; 107: 241-246.

36. Nakshatri H, Bhat-Nakshatri P, Martin DA, Goulet RJ Jr, Sledge GW Jr. Constitutive activation of NF-kappaB during progression of breast cancer to hormone-independent growth. Mol Cell Biol 1997; 17: 3629-3639.

37. García-Piñeres AJ, Castro V, Mora G, Schmidt TJ, Strunck E, Pahl HL et al. Cysteine 38 in p65/NF-kappaB plays a crucial role in DNA binding inhibition by sesquiterpene lactones. J Biol Chem 2001; 276: 39713-39720.

38. Kwok BH, Koh B, Ndubuisi Ml, Elofsson M, Crews CM. The anti-inflammatory natural product parthenolide from the medicinal herb Feverfew directly binds to and inhibits IkappaB kinase. Chem Biol 2001; 8: 759-756.

39. Niemann A, Takasuki A, Elsässer HP. The lysosomotropic agent monodansylcadaverine also acts as a solvent polarity probe. J Histochem Cytochem 2000; 48: 251-258.

40. Mizushima N, Yoshimori T. How to interpret LC3 immunoblotting. Autophagy 2007; 3 : 542-545.

41. Park KJ, Lee SH, Lee CH, Jang JY, Chung J, Kwon MH et al. Upregulation of Beclin-1 expression and phosphorylation of $\mathrm{Bcl}-2$ and p53 are involved in the JNK-mediated autophagic cell death. Biochem Biophys Res Commun 2009; 382: 726-729.

42. Wei $\mathrm{Y}$, Sinha S, Levine B. Dual role of JNK1-mediated phosphorylation of Bcl-2 in autophagy and apoptosis regulation. Autophagy 2008; 4: 949-951.

43. Vrekoussis T, Chaniotis V, Navrozoglou I, Dousias V, Pavlakis K, Stathopoulos EN et al. Image analysis of breast cancer immunohistochemistry-stained sections using ImageJ: an RGB-based model. Anticancer Res 2009; 29: 4995-4998.

44. Riganti C, Doublier S, Viarisio D, Miraglia E, Pescarmona G, Ghigo D et al. Artemisinin induces doxorubicin resistance in human colon cancer cells via calcium-dependent activation of HIF-1alpha and P-glycoprotein overexpression. Br J Pharmacol 2009; 156 : 1054-1066.
45. Price LS, Langeslag M, ten Klooster JP, Hordijk PL, Jalink K, Collard JG. Calcium signalling regulates translocation and activation of Rac. J Biol Chem 2003; 278 : 39413-39421.

46. Kim YS, Morgan MJ, Choksi S, Liu ZG. TNF-induced activation of the Nox1 NADPH oxidase and its role in the induction of necrotic cell death. Mol Cell 2007; 26 675-687.

47. Scherz-Shouval R, Shvets E, Fass E, Shorer H, Gil L, Elazar Z. Reactive oxygen species are essential for autophagy and specifically regulate the activity of Atg4. EMBO J 2007; 26 1749-1760.

48. Zhang N, Chen $Y$, Jiang R, Li E, Chen X, Xi Z et al. PARP and RIP 1 are required for autophagy induced by 11'-deoxyverticillin $A$, which precedes caspase-dependent apoptosis. Autophagy 2011; 7: 598-612.

49. Feoktistova M, Geserick P, Kellert B, Dimitrova DP, Langlais C, Hupe M et al. clAPs block ripoptosome formation, a RIP1/caspase-8 containing intracellular cell death complex differentially regulated by cFLIP isoforms. Mol Cell 2011; 43: 449-463.

50. Oka D, Nishimura K, Shiba M, Nakai $Y$, Arai $Y$, Nonomura $N$ et al. Sesquiterpene lactone parthenolide suppresses tumor growth in a xenograft model of renal cell carcinoma by inhibiting the activation of NF-kappaB. Int J Cancer 2007; 120: 2576-2581.

51. Asare N, Lag M, Lagadic-Gossmann D, Rissel M, Schwarze $P$, Holme JA. 3-Nitrofluoranthene (3-NF) but not 3-aminofluoranthene (3-AF) elicits apoptosis as well as programmed necrosis in Hepa1c1c7 cells. Toxicology 2009; 255: $140-150$.

52. Wang $\mathrm{H}$, Joseph JA. Quantifying cellular oxidative stress by dichlorofluorescein assay using microplate reader. Free Radic Biol Med 1999; 27: 612-616.

53. Dikalov S, Landmesser U, Harrison DG. Geldanamycin leads to superoxide formation by enzymatic and non-enzymatic redox cycling. Implications for studies of $\mathrm{Hsp90}$ and endothelial cell nitric-oxide synthase. J Biol Chem 2002; 277: 25480-25485.

54. Munafò DB, Colombo Ml. A novel assay to study autophagosome vacuole size by aminoacid deprivation. J Cell Science 2001; 114: 3619-3629.

55. Carlisi D, D'Anneo A, Angileri L, Lauricella M, Vento R, Tesoriere G et al. Parthenolide sensitizes hepatocellular carcinoma cells to TRAIL by inducing the expression of death receptors through inhibition of STAT3 activation. J Cell Physiol 2011; 226: 1632-1641.

56. Cao C, Healey S, Amaral A, Lee-Couture A, Wan S, Kouttab N et al. ATP-sensitive potassium channel: A novel target for protection against UV-induced human skin cell damage. J Cell Physiol 2007; 212: 252-263.

57. Giuliano M, Lauricella M, Calvaruso $G$, Carabillò $M$, Vento $R$, Tesoriere $G$ et al. The apoptotic effects and synergistic interaction of sodium butyrate and MG132 in human retinoblastoma Y79 cells. Cancer Res 1999; 59: 5586-5595.

58. Lowry $\mathrm{OH}$, Rosebrough NJ, Farr AL, Randall RJ. Protein measurement with the folin phenol reagent. J Biol Chem 1951; 193: 265-275.

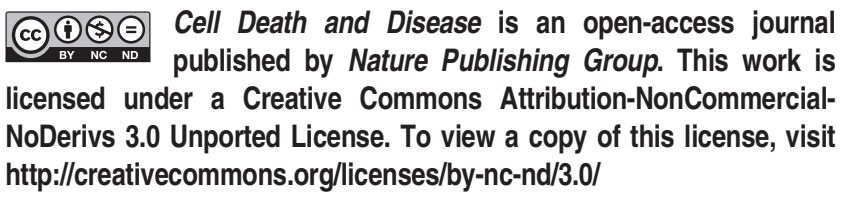

(c) (i) (-) $\odot$ Cell Death and Disease is an open-access journal licensed under a Creativ Commons Attibution-NonCommerciatNoDerivs 3.0 Unported License. To view a copy of this license, visit http://creativecommons.org/licenses/by-nc-nd/3.0/

Supplementary Information accompanies this paper on Cell Death and Disease website (http://www.nature.com/cddis) 